\title{
EL RETORNO DE LOS JESUITAS A MÉXICO EN EL SIGLO XIX: ALGUNAS PARADOJAS*
}

\author{
Guillermo Zermeño Padilla \\ El Colegio de México
}

INTRODUCCIÓN

T a historia del retorno de los jesuitas a México después Lde su expulsión en 1767 ya ha sido contada y documentada varias veces. Las dos obras más influyentes - en deuda en este nuevo recorrido - son los escritos del presbítero Mariano Dávila y Arrillaga (1798-1869) y los dos volúmenes del historiador jesuita, nacido en Francia, Gerardo Decorme (1874-1965). ${ }^{1}$ En su exposición, el segundo se apoya en

Fecha de recepción: 20 de septiembre de 2013

Fecha de aceptación: 19 de agosto de 2014

\footnotetext{
* Agradezco a Pilar Vallés, Rubén Aguilar y Gabriel Torres Puga por su lectura atenta e interesada de versiones anterores. Sus comentarios y sugerencias, y los de los dictaminadores anónimos, me han sido de gran provecho y estímulo. Este ensayo es una nueva versión del que apareció en el libro Antijesuitismo y filojesuitismo: dos identidades ante la restauración, Universidad Iberoamericana, 2014, y es avance de una investigación más amplia sobre el jesuista Basilio M. Arrillaga.

${ }^{1}$ Dávila y Arrillaga, Continuación; Decorme, Historia de la Compañia de Jesús en la República Mexicana.
} 
el primero, si bien Decorme ${ }^{2}$ intentará deslindarse de la forma como Dávila da cuenta de dicho regreso a suelo novohispano en 1816. Desde el comienzo Decorme lo asocia a la causa de los insurgentes novohispanos en contra del régimen virreinal. Para ello se apoya en algunas supuestas palabras pronunciadas por Morelos - en el marco de la formación de la Constitución de Apatzingán de 1813 - sobre las ventajas del restablecimiento de los jesuitas, ${ }^{3}$ originalmente suscritas por Carlos M. Bustamante - con fines apologéticos - dos décadas después de la independencia, en un momento político, como veremos (1841-1842), favorable a la "reposición" de los jesuitas. ${ }^{4}$

${ }^{2}$ Decorme escribe como integrante de una provincia mexicana que había ido recuperando terreno a partir de 1880 . Había llegado a México por su relación con el jesuita español José Artola (1818-1887), quien realizó sus estudios entre Bélgica y Francia, y que llegó a México como visitador de la provincia mexicana a principios de 1866. Precisamente Artola sustituiría al padre Basilio Arrillaga, fallecido en 1867, como provincial. Decorme fue compañero de otros jesuitas como Marcelo Renaud, Bernardo Bergoend y Martin Dauvergne. Hizo su noviciado y juniorado en la antigua hacienda de San Simón en Michoacán entre 1893 y 1896. En 1899 llegó como profesor al Colegio de Saltillo y en 1909 se integrará como escritor en la residencia de Los Ángeles de la ciudad de México. Debido a la crisis revolucionaria de 1913 y el nuevo exilio jesuítico residirá en Isleta College a partir de 1916.

${ }^{3}$ Decorme tomó prestadas las palabras del líder insurgente, "Yo amo de corazón a los Jesuitas y, aunque no estudié con ellos, entiendo que es necesidad reponerlos", recogidas por el historiador Carlos Bustamante personalmente en 1813 y que introdujo en el prólogo a la edición en 1841-1842 de la obra del jesuita Francisco Javier Alegre. Historia de la Compañia de Jesús en Nueva-España, t. III que estaba escribiendo el P. Francisco Javier Alegre al tiempo de su espulsión.

${ }^{4}$ Expresión de Bustamante: "Publícala para probar la utilidad que prestará a la América Mexicana la solicitada reposición de dicha compañía Carlos María Bustamante, individuo del Supremo poder Conservador”. 
Desde luego, el trabajo de Decorme se ha enriquecido con la organización y consulta de nuevos archivos, que seguramente no estuvieron al alcance de Dávila. En defensa de los valores de una historia científica y objetiva, Decorme se ha esforzado, sin conseguirlo del todo, en evitar juicios políticamente comprometedores en un momento en que parecían haberse normalizado las relaciones entre el gobierno y la institución jesuítica. En función de dicha "objetividad" Decorme intentará responder también a los detractores de los jesuitas.

Por el contrario, la narración de Dávila ${ }^{5}$ se estructura como una crónica de sucesos al modo de historiadores como Bustamante. En dicha relación se enfatizan las líneas de continuidad entre la antigua y la nueva Compañía; por un lado, entre la "interrumpida" en 1767, por decreto de Carlos III y la extinción de 1773 por bula del papa Clemente XIV, y por el otro, la restaurada en 1814 por decreto del papa Pío VII y la nueva confirmación por Fernando VII en 1815. La obra de Dávila puede inscribirse igualmente dentro de la tradición historiográfica jesuítica del siglo xviII al conjuntar la descripción de los hechos dignos de recordar con la memoria de los jesuitas ilustres. La exposición se concentra en los sucesos de la primera mitad del siglo xix hasta la tercera extinción de 1855. Por esa razón el trabajo de Dávila puede enmarcarse en

Historia de la Compañia de Jesús en Nueva-España. Véase también de Bustamante, El Gabinete mexicano durante el segundo periodo... 1842, pp. 122-128.

5 Dávila y Arrillaga, sobrino del padre Basilio Arrillaga, fue novicio jesuita en 1818, y tras la extinción de 1821, exjesuita, casado y viudo. Finalmente fue consagrado como presbítero por el obispo Clemente de Jesús Munguía (1810-1868). 
la intensificación del conflicto entre simpatizantes y enemigos de los jesuitas originada por el nuevo restablecimiento de 1853 favorecido por la llegada otra vez al poder de Antonio López de Santa Anna, y rápidamente contestada por el líder liberal Juan Álvarez, que condujo (una vez más) a la desaparición de la institución jesuítica en 1856 . $^{6}$

Tal vez por esa razón, más su fallecimiento en 1869, Dávila no pudo ver impreso su manuscrito, si bien algunos avances fueron publicados en un escrito anónimo de 1850.7 Los dos volúmenes de Dávila fueron rescatados en la década de 1880 y editados bajo el sello del colegio de los jesuitas en Puebla. Vista en conjunto se aprecia una obra que intenta vindicar la fama de los jesuitas tras su "injusta" e inexplicable extinción de 1821, exhibiendo en la trama una gran cantidad de "pruebas" y documentos. Este carácter la convierte en un libro archivo ambulante sumamente valioso para esta investigación, ya que a través de sus páginas se despliega una serie archivística dedicada a la "nueva compañía”, pero sobre todo, estructurada a partir del modo como se van sucediendo los acontecimientos. Como se señaló, este "archivo" será luego retomado y ampliado por Decorme, de ahí la importancia de ambos trabajos.

Después, la obra del jesuita francés sufrirá un cierto oscurecimiento debido a la nueva diáspora y dispersión de los jesuitas a raíz del movimiento social y político iniciado a

${ }_{6}^{6}$ Para una visión ampliada del conflicto véase Knowlton, "La Iglesia mexicana y la reforma", y Los bienes del clero.

${ }^{7}$ Suscrito en forma anónima "por un testigo ocular de la mayor parte de ellos". Los jesuitas en México, o memorias para servir a la historia del restablecimiento, destrucción y otros sucesos relativos a la Compañia de Jesús, en la República Mexicana, desde 1816 hasta la fecha, 1850. 
fines de 1910, cuyas secuelas serán visibles hasta el conflicto religioso y político militar de 1926-1929. ${ }^{8}$ La intensificación de esta disputa entre la Iglesia y el Estado revolucionario se intentará traspasar y distensionar con la aparición de una nueva generación de historiadores jesuitas, representantes de una “nueva compañía” estabilizada y resurgida después de 1930. Ahí se destacará en primer lugar la obra del padre José Gutiérrez Casillas, ${ }^{9}$ recientemente fallecido, en la cual se descubre la huella del padre Decorme, así como se ve enriquecida con nuevos materiales y fuentes. Le sigue el trabajo del padre Esteban Palomera, enfocado sobre todo a la obra educativa de los jesuitas en Puebla, ${ }^{10}$ aunque pondrá también atención a algunos aspectos relacionados con el retorno de los jesuitas.

En las obras mencionadas existe sin duda un hilo que entrelaza y da continuidad a la antigua y la nueva "compañía”, una elaboración que nos remite al mismo siglo xix. A contracorriente de esta “versión”, en este ensayo se dará una especial relevancia al desgarramiento político suscitado por los acontecimientos de 1808-1821, una transformación radical en el régimen de dominación política. La consideración de esta mutación tal vez permita entender con otras bases la forma tan accidentada y llena de obstáculos que tuvo el "retorno" y "restablecimiento" de los jesuitas. La atención prestada a dichas "dificultades" da lugar en bue-

${ }^{8}$ Jesuitas en México durante el periodo 1816-1900: 1816: 15; 1820: 37; 1830: 22; 1840: 14; 1850: 10; 1860: 14; 1870: 25; 1880: 48; 1885: 67; 1890: 140; 1900: 245. Churruca, "Historia de la Provincia Mexicana de la Compañía de Jesús”, p. 25.

9 Gutiérrez Casillas, Jesuitas en México durante el siglo XX. Del mismo autor véase "La nueva CJ desde 1814", pp. 2651-2656.

10 Palomera, La obra educativa de los jesuitas. 
na medida a los entresijos de un relato construido a partir de "paradojas". ${ }^{11}$ Las propias de lo que significaría pensar en la reinserción de una institución religiosa surgida en otro siglo y determinada ahora por la transformación de las reglas del juego político y cultural. Así, se podrá observar que los hijos de san Ignacio retornados a Nueva España en 1816, al tiempo que se esforzaron en reactualizar su tradición y su ideario -incluso mimetizar las formas establecidas desde su casa matriz romana (la Iglesia del Jesú) - tuvieron que enfrentar situaciones no previstas ni por sus fundadores ni por sus padres espirituales.

\section{EL RETORNO}

En primer lugar, los jesuitas pudieron regresar porque fueron convocados por la máxima autoridad del catolicismo romano, el papa Pío VII, y por el monarca español, Fernando VII, para servir de contrapeso a la avanzada del liberalismo. En dicho acontecimiento se combinan dos tipos de hechos, uno de corte intelectual y otro de orden político militar. El primero se relaciona con el movimiento de los llamados "filósofos ilustrados"12 y el segundo - cronológicamente posterior - se condensa en la figura de Napoleón y la reconfiguración general de Europa y de la geopolítica mundial.

11 Una paradoja, en general, es lo contrario de la opinión o sentido común. Designa ese "algo" que no es fácil de explicar y que pone el acento en ese espacio (prelógico) que contradice toda lógica. Por eso la paradoja circula a contrapié de las certezas lógicas de lo verosímil. Véase VIDAL-RosSET, Qu'est-ce qu'un paradoxe.

12 Sobre la evolución y complejidad del concepto, Gumbrecht, “¿Quiénes fueron los philosophes?”. 
En segundo término, la restauración de los jesuitas en la capital del virreinato novohispano en 1816 fue posible en buena medida por la fortuna económica y el apoyo político de la familia Castañiza, en particular del Marqués Juan Francisco Castañiza (1756-1825), el más joven de los tres hermanos. José María, el mayor, había ingresado a la orden jesuítica antes de la expulsión y regresado a México del exilio poco antes del restablecimiento, llegando a ser el primer provincial de la Compañía restaurada. Precisamente Juan Francisco heredó el título paterno hacia $1794,{ }^{13}$ debido a que José María, por ser jesuita, estaba impedido para ostentar cualquier título nobiliario. Juan Francisco, a su vez, siendo marqués, había hecho carrera eclesiástica y llegado a ser comisario de corte de la Inquisición, rector de la Universidad de México, catedrático y rector del Colegio de San Ildefonso, la antigua casa de formación jesuítica.

Durante la crisis del Ayuntamiento de la capital virreinal, en septiembre de $1808,{ }^{14}$ el Marqués de Castañiza se alineó con el bando contrario al del virrey Iturrigaray, compuesto por miembros de la Sociedad Bascongada, como Gabriel Yermo, que defendía los intereses de la Audiencia y de sectores mercantiles de Cádiz. Dicha confrontación no se puede reducir a una lucha entre "criollos" y "peninsulares" ya que en los dos bandos hay unos y otros, ${ }^{15}$ aunque conforme se desen-

13 Zárate Toscano, Los nobles ante la muerte en México, p. 364.

${ }^{14}$ Ocasionada por la invasión de las tropas napoleónicas a la península Ibérica y la abdicación de la corona por Fernando VII, a lo cual se sumó el decreto imperial de 6 de junio de 1808 que proclamó a José Bonaparte rey de España y de las Indias.

${ }^{15} \mathrm{Al}$ respecto véase la versión clásica de VILLORO, "La revolución de independencia", en Historia General de México, pp. 498-504; GuedeA, 
vuelvan los acontecimientos se abrirá una brecha insalvable entre "europeos" y "americanos".

Más tarde Castañiza integraría el tribunal que condenó a Morelos a la degradación sacerdotal antes de su ejecución en diciembre de 1815. Por su lealtad Fernando VII lo recompensó con el obispado de Durango en 1815, el mismo año en que el monarca decretó el restablecimiento de los jesuitas en los "Reinos de Indias y Filipinas". ${ }^{16}$ En ese sentido, la familia Castañiza, al hacer posible la restauración de los jesuitas en la capital virreinal en mayo de 1816, estaba situada abiertamente del lado contrario al de los "insurgentes". ${ }^{17}$

Como sabemos, en el bando que defendía la autoridad del virrey Iturrigaray se encontraban, entre otros personajes, fray Servando Teresa de Mier, quien escribió su famosa Historia de la revolución de Nueva España ${ }^{18}$ tras la muerte de Hidalgo en 1811 y el decaimiento del movimiento insurgente, en defensa de los agravios cometidos al grupo que él representaba. En principio Mier sostenía que esa "revolución" no se asemejaba en nada a la francesa. Intentar compararla significaba agraviar a la Nueva España, reino "agobiado por los impuestos [...]" (Mier, 1813, p. 125). Al hacer uso de la

\footnotetext{
"La independencia (1808-1821)", pp. 147-150. Sobre la versión "criolla" véase GonZÁLEZ, "El periodo formativo", pp. 83-84. Esta aproximación se matiza en VÁzQuez, "De la independencia a la consolidación republicana”, pp. 140-141.

${ }^{16}$ El decreto real se refiriere también, como una de las razones para el restablecimiento de los jesuitas, a las sesiones del 16 y 31 de diciembre de 1810 de las Cortes de Cádiz en las que 29 de los 30 diputados de ultramar habrían solicitado la reinstalación de la Compañía en sus provincias. Revuelta González, “Claves históricas”, pp. 286-287.

${ }^{17}$ Más información en Zermeño, "Recuerdo ritual”, pp. 140-142.

${ }_{18}$ Mier, Historia de la revolución de Nueva España, 1813.
} 
etimología esclarecía los términos "insurgencia” y "revolución”. El primero se derivaba del latín insurgo o "levantarse el que está caído", y por tanto connotaba un título honorífico; el segundo provenía "del verbo revolvo, que en Cicerón significa volver otra vez o hacia atrás; con que si lo de atrás fuere mejor, la revolución será [...]" (Mier, 1813, p. xvi). Finalmente, acusaba a López Cancelada, diputado por México en las Cortes, de estar "dominado por el espíritu de intriga, de revolución, maledicencia, pasquinada y calumnia” (Mier, 1813, p. 161). Fueron los "anuncios de la abdicación [en 1808] [...] los que prepararon la revolución” (Mier, 1813, p. 289). Así, por qué sorprenderse de que los eclesiásticos hubieran encabezado la "revolución..." (Mier, 1813, p. 280). ${ }^{19}$

Estos aspectos iniciales significarían, por tanto, que los jesuitas al retornar aparecen como defensores de la restauración del "antiguo régimen" o monarquistas, "restauración" que implicaba la persecución de los "liberales", la abolición de la Constitución de Cádiz de 1812, el regreso de la Inquisición, ${ }^{20}$ la anulación de la libertad de prensa y, desde luego, la persecución y aniquilamiento de los insurgentes. En

${ }^{19}$ Véase Zermeño, “México/Nueva España”, pp. 153-168.

20 Sobre el retorno de la Inquisición véase TorRes Puga, "Las dos supresiones de la Inquisición en México”, pp. 133-159. Entre las desapariciones y el nuevo restablecimiento se observa una suerte de desfiguración de dicho Tribunal. En el futuro los jesuitas tendrán que pagar el costo de asociar su "restauración" con la de la Inquisición. Un ejemplo es la "Humorada", El Monitor Republicano (5 oct. 1849), p. 4. "Ya vienen ahí los jesuitas/Con cruz alta y con ciriales, / Para remediar los males/ Que afligen a la nación/ glin, glon glon. // Y detrás de los jesuitas, /Castigando pecadores/Vienen los inquisidores, / Con su cuarta y su tizón/ Según la constitución.// Y detrás de todos estos/Viene el rey... de Dios enviado; /Y donde él esté sentado/No ha de haber otro mandón”. 
ese sentido la institución jesuítica era contraria a la independencia de México representada en ese momento por la Constitución de Apatzingán (1814).

En tercer lugar los jesuitas son invitados por el papa Pío VII y el rey Fernando VII para librar una nueva batalla intelectual, esta vez contra los filósofos ilustrados. Una lucha en contra de lo que en el campo de las ideas y de las creencias se calificaba en ese momento como "materialismo", "deísmo", "irreligión”, "filosofismo", “enciclopedismo”. De hecho, algunos jesuitas al regresar advirtieron que si no hubieran sido expulsados anteriormente este movimiento intelectual no hubiera ganado tanto terreno en territorio novohispano.

Así, los jesuitas regresaron a Nueva España amparados por la bula papal y el decreto del monarca borbón. Y al tomar posesión de nuevo del antiguo Colegio real de San Ildefonso contaron con la venia y simpatía de la autoridad civil, el virrey Calleja, y de la autoridad eclesiástica, el arzobispo electo de México, Pedro José de Fonte. Las ceremonias de entrega y restauración oficial se realizaron el 19 de mayo de 1816, para dar pie luego a las actividades pastorales y educativas tradicionales, y a la apertura del noviciado para formar a los nuevos jesuitas. ${ }^{21}$ Muchos de los reclutados eran estudiantes del mismo Colegio y otros ya eran sacerdotes formados. También se reincorporaron algunos jesuitas retornados de Italia, como el padre José María Castañiza y otros célebres como el padre Pedro José Márquez, e incluso se pensaba incorporar otros jesuitas de Alemania e Italia.

${ }^{21}$ Sobre las “ceremonias de restauración”, Zermeño, "Recuerdo ritual”, pp. 142-146. 
En ese sentido, sin considerar la inquietud generada por el movimiento insurgente, cuando regresaron parecía, en efecto, que sólo se estaba reanudando lo que se había interrumpido abruptamente en 1767. De hecho, muy pronto, durante esos años de 1816-1820, comenzaron a llegar solicitudes para su restablecimiento en otros lugares, notoriamente de Puebla, a donde llegarían a fines de 1819, lo mismo que a Durango, amparados e invitados por el obispo Marqués de Castañiza. Al mismo tiempo, para su restablecimiento se había formado una Junta especial a fin de proveer y hacer viables la entrega de bienes y edificios ("temporalidades") para el desarrollo de sus obras.

Sin embargo, para 1820 no se contaba con el retorno de los "vencidos", los "liberales", que regresarían al poder por medio de un golpe de timón y restablecerían la Constitución de Cádiz de 1812, que delimitaba el poder absoluto del monarca mediante el restablecimiento de las Cortes. Debido a esto la suerte de los jesuitas se verá fuertemente afectada por el hecho de haber retornado gracias al poder de la monarquía "absoluta". Caída en desgracia, el poder del monarca quedó subordinado a las Cortes, y con él todos sus validos -instituciones como la Inquisición, ${ }^{22}$ la Compañía de Jesús y otras órdenes hospitalarias-. Al no contar más con su protección tradicional, los jesuitas quedarían expuestos, a la intemperie.

${ }^{22}$ Véase Torres PugA, "El último aliento de la Inquisición”. El retorno y la supresión de la Inquisición pueden verse como una historia paralela a la de los jesuitas. En su ensayo Torres Puga muestra bien cómo dentro del sistema imperial no existía más una coherencia completa, si es que alguna vez la pudo haber en el pasado. En una época de "crisis" se despierta una lucha de atribuciones en el sistema. Por ejemplo entre la autoridad del virrey y la de la Inquisición, o la de la Audiencia. 
Lo extraño, como se verá, es que dejarán de contar incluso con el poder y la influencia del monarca, o cuando sea el caso, del mismo Iturbide, por más que hubieran mayores afinidades y simpatías ideológicas que con otros.

Se trataría entonces de saber cómo los jesuitas se reinscribieron en la vida "nacional" a partir del establecimiento de nuevas reglas políticas. Dicha reinserción hasta cierto punto implicó tener que hacerlo a partir de cero. En ese intersticio cobrará gran importancia la lucha librada en el ámbito de la opinión pública entre sus defensores y sus detractores. Por mediación de esta esfera - regulada ahora por el principio de la libertad de prensa y de opinión entendida en gran parte como el eco público de las resoluciones y debates habidos en el Congreso - durante el siglo xIx los jesuitas intentarán ganarse de nuevo la benevolencia del público y su reconocimiento.

El problema, y de ahí su complejidad, es que en ese debate, en esa lucha entre simpatizantes y opositores, se reciclarán muchas imágenes (positivas o negativas) del pasado acumuladas durante su historia. En tal caso, será interesante observar cómo al mismo tiempo que los liberales se inventaron un pasado como "ilustrados" y portadores de la "verdadera" ilustración para construir un futuro mejor, los jesuitas tendrán que ser reinventados como precursores de la independencia y como “ilustrados”. Esa “invención” comenzará a perfilarse a partir de la década de 1830, precisamente cuando se libre una nueva lucha en las Cámaras por su restablecimiento. En dicha tarea habrá sin duda muchos simpatizantes, pero destacará entre todos la figura del historiador Carlos M. Bustamante, en particular cuando tengan lugar los reconocimientos parciales o fugaces de 1843 y 1853 . No obstante 
lo anterior, ya en plena dominación del régimen liberal, no faltarán expresiones provenientes del campo enemigo elogiosas de la "escuela jesuítica" de educación, valorada como un modelo ideal para hacer extensivo el concepto de escuela universal propio del régimen republicano. ${ }^{23}$ Lo cual no deja de ser paradójico.

\section{DE NUEVO EN SAN ILDEFONSO}

Basados en lo anterior, se puede afirmar expost facto que los jesuitas retornaron en el peor momento. No obstante, desde su óptica esta afirmación podría ser cuestionable ya que sus sueños y expectativas eran regresar y obtener de nuevo el respeto y la aceptación públicos. Pero es verdad también que la restauración de la "milicia ignaciana" en 1814 se presentó cuando las monarquías y Europa ya no eran las mismas de 1767. En el caso de la orden jesuítica, poderosa hasta antes de su expulsión, retornaba ahora en un momento de profunda inquietud e incertidumbre y, sobre todo, de gran debilidad de la institución eclesiástica. Lo único cierto es que su regreso se dio en los márgenes de la restauración de la dinastía borbónica - personificada en el regreso del "deseado" Fernando VII al trono en 1814-, la misma que unas décadas antes había decretado su supresión. Este hecho ambivalente en cierto modo marcará su suerte en el futuro. ${ }^{24}$

${ }^{23}$ Véase el elogio del liberal positivista Gabino Barreda en Hale, La transformación del liberalismo en México, pp. 158-159; 230-231; 240-241. ${ }^{24}$ Para algunos estudiosos esta "marca" está presente por lo menos hasta la apertura del Concilio Vaticano II. Revuelta González, "Claves históricas", pp. 284-286. 
La restauración de los jesuitas se relaciona con algunas fechas relevantes. El 19 de marzo de 1812 se promulgó la Constitución política de la Monarquía española en Cádiz que, entre otras cosas, circunscribió el poder político de los monarcas, desapareció el Tribunal de la Inquisición y decretó la libertad de prensa. Sin embargo, tras la debacle del emperador Napoleón en Rusia sólo dos años después, el 4 de mayo de 1814, Fernando VII reasumió el trono de España. Lo primero que hizo fue disolver las Cortes y anular la Constitución de 1812. Pocos meses después, el 31 de julio de 1814, fiesta de San Ignacio, resolvió restablecer la Compañía de Jesús en sus dominios. El papa Pío VII ratificó la restauración de la orden el 7 de agosto. Sólo un año después, el 30 de mayo de 1815 (conforme a un decreto de 29 de mayo), los jesuitas fueron "repuestos" oficialmente en el orbe de la Monarquía española, lo cual implicó la derogación del decreto de expulsión expedido en 1767 por Carlos III, abuelo de Fernando. Junto con los jesuitas Fernando VII tuvo a bien restablecer el Tribunal de la Inquisición por decreto de 21 de julio de 1815. Por eso, desde la perspectiva de sus adversarios, casi será inevitable que se identifique su retorno con el estigma de la "reacción" o la "restauración", teniendo en cuenta la revolución liberal representada por las Cortes de 1812 que le precedieron. Al restablecerlos en septiembre de 1815, Fernando VII proyectaba convertirlos en un ariete defensivo en contra del "liberalismo". De hecho, ese mismo año emprendería una persecución de los liberales españoles que atentaban contra la monarquía. Quien representaría esta tarea en la capital de la Nueva España sería el arzobispo de México, 
Pedro José Fonte, ${ }^{25}$ mismo que avalaría su retorno oficializado en 1816. La paradoja inscrita en la forma como se dio dicho restablecimiento estriba en que la misma casa dinástica que los expulsó, por entender que podrían ser un obstáculo para emprender sus reformas administrativas, ahora los necesitaba para luchar contra la anarquía. Todavía peor, su regreso coincidió con la petición expresa del papa Pío VII a los americanos (30 de enero de 1816) de no apoyar las luchas insurgentes favorecedoras de las independencias. ${ }^{26}$

\section{HACIA LA SEGUNDA SUPRESIÓN}

Hasta 1819 parecía que todo transcurría de acuerdo a lo esperado. Si en mayo de 1816 había 15 jesuitas, entre sacerdotes, escolares y coadjutores, para 1820 se había incrementado el número a más del doble (39). ${ }^{27}$ Había razones para el optimismo, incluso el movimiento insurgente había entrado en una etapa de recesión. El 18 de diciembre de 1819 cuatro jesuitas se habían desplazado a Puebla para retomar la Iglesia de la Compañía, entre ellos los padres Ignacio Lerdo de Tejada $a^{28}$

${ }^{25}$ Desde la perspectiva de Fonte el término "liberal" era sinónimo de "filosofismo", ideología que impregnaba supuestamente al bando rebelde de los insurgentes. La sanción arzobispal en su contra se plasmó en un opúsculo crítico de la Constitución de Apatzingán de 1814. GonZÁLez Araujo, Impugnación.

${ }^{26}$ Encíclica Etsi longissimo. Olmedo, Manual de historia de la Iglesia, t. III, p. 263.

${ }^{27}$ Catalogus...1820. Biblioteca Nacional de España (BNE).

28 Doctor en teología, rector del Seminario de Minería en México, presbítero del oratorio de san Felipe Neri de México. Nació el 29 de julio de 1786 e ingresó en el noviciado jesuita el 5 de enero de 1817. Tío de Miguel y Sebastián Lerdo de Tejada. 
- futuro asistente del padre general Jan Phillip Roothaan - y Basilio M. Arrillaga, ambos doctores en teología que habían concluido su noviciado el año anterior..$^{29}$ En ese contexto el padre provincial había solicitado al asistente general situado en Madrid, el padre Zúñiga, que tramitara la revocación del decreto de extinción de las cátedras jesuitas. ${ }^{30}$ Pese a todo, en junio de 1820 comenzaron a aparecer nuevos signos de turbulencia que exigían mantener una comunicación más expedita entre Madrid y México. Las tropas españolas destinadas a Buenos Aires y capitaneadas por el coronel Rafael de Riego se habían rebelado contra la orden del rey y proclamado el $1^{\circ}$ de enero de 1820 el restablecimiento de la Constitución de Cádiz de 1812, la cual sería jurada por Fernando VII el 9 de marzo.

La información de Madrid comenzó a propagarse en México apenas el 29 de abril, al tiempo que el virrey Apodaca trataba de impedir que circulara, mientras los miembros de la Audiencia y el arzobispo Fonte acordaban qué hacer. Entre tanto se iban formando juntas, unas para aclamar la Constitución y otras-organizadas por el canónigo Matías de Monteagudo y Agustín de Iturbide- para impedir su publicación, basados en argumentos similares a los de la crisis de 1808: el rey estaba bajo presión y por tanto había que remitirse para gobernar a las Leyes de Indias con independencia de España. ${ }^{31}$

29 Dávila y Arrillaga, Continuación, p. 223. Una relación del regreso de los jesuitas a Puebla más profusa, en Decorme, Historia, pp. 170-177.

30 Zermeño, "La filosofía jesuita novohispana en perspectiva”, pp. 78-87; “Libros jesuitas incautados y proscritos”, pp. 61-68.

31 Decorme, Historia, p. 181. Aquí sigue a Alamán, Historia de Méji- 
En la comunicación del padre provincial Pedro Cantón con el padre Zúñiga, además de los informes sobre las actividades y defunciones de los jesuitas, se advierten las preocupaciones por la información que llegaba sobre las juras de la Constitución por el virrey el 31 de mayo de 1820 y las comunidades religiosas, incluida la jesuítica, ${ }^{32}$ que obligaban a suspender muchas de las actividades programadas, como recibir una nueva generación de novicios. ${ }^{33}$

El mes siguiente a la jura de la Constitución por los jesuitas y religiosos, el arzobispo Fonte emitió un edicto el 16 de julio, en el que mandaba respetar a todos sus ministros la orden de jura de la Constitución que acotaba los poderes de la monarquía. Acatada por la cabeza de la monarquía y al no tratarse de algo en contra de Dios, todos por igual debían rendir obediencia a la "legítima potestad civil". Por tanto, no cabía ninguna posibilidad de resistencia o desobediencia por parte de los "ciudadanos". Ante todo, y poniendo de por medio la carta de san Pablo a los romanos, habría que buscar la conservación de "la tranquilidad y el orden público", en la medida en que toda autoridad legítimamente constituida provenía de Dios. En ese sentido, el rey y los representantes electos tenían que ser respetados por los ciudadanos al ser funcionarios de Dios en la tierra.

Co, p. 17. Versión que luego recogerá GonZÁLEz, "El periodo formativo", pp. 90-91.

32 A la jura de la Constitución por los religiosos antecede la orden del virrey, al cual antecede el ejemplo dado por el rey Fernando VII. Véase García Díaz, Independencia nacional, t. II, pp. 280-281. Se reproduce un texto de la Gaceta del gobierno de México (19 jun. 1820), t. XI, núm. 67, pp. 527-529.

${ }^{33}$ Carta del padre Cantón al padre Zúñiga (Madrid), junio de 1820. AHPM, GD, carp. XXIII. 
El contenido del edicto es interesante porque muestra el modelo deseable de la forma de gobierno. Para el arzobispo, la "anarquía" (representada por el movimiento social disidente surgido de los hechos del 15 de septiembre de 1808) será siempre más funesta que el "despotismo": "Es menos duro el capricho de uno que el de todos". No obstante, los eclesiásticos habrían de inclinarse siempre a favor de la reconciliación y la concordia, y en ese sentido se debía prescindir "de los partidos opuestos y relaciones personales", ya que se era parte de "la sociedad civil". Por eso debía evitarse cualquier provocación. Asumido el respeto y salvaguarda de la Constitución sólo quedaban dos aspectos a considerar: el primero, relacionado con la desaparición del Tribunal de la Inquisición (incluidas sus "temporalidades"), y el segundo, con la libertad de prensa. Respecto al Tribunal, solicitaba de los curas parroquiales estar atentos para recoger de la circulación todos los papeles subversivos que atentaran contra la fe, así como para recibir de los fieles cualquier clase de denuncias, avisos o infracciones. Debían funcionar, en ese sentido, como si fueran "Comisarios del Santo oficio". En relación con el segundo aspecto, recomendaba el uso del "ortodoxo y admirable” Catecismo tridentino publicado por el papa Pío V (que preserva al pueblo de la "falsa devoción" y cimienta "la verdadera”) para contrarrestar la influencia de la circulación de los "libelos irreligiosos que ofenden la piedad verdadera". Advertía en seguida que no debía confundirse la verdadera libertad "racional y honesta" con libertinaje o "licencia de hacer quanto sugiriese el capricho, o el ímpetu de las pasiones: y cada uno hallará los límites de su libertad preciosa, al observar que gozando de lo mismo sus conciudadanos, no la tienen para hacerle mal". Los fieles debían precaverse de confundir 
el significado amplio de los términos "libertad e igualdad" con el sentido restringido dado en la Constitución, otorgado a "libertad civil e igualdad política". De tal modo que, en efecto, los ciudadanos eran "libres de toda arbitrariedad y gravamen injusto, pero subordinado a la ley". Asimismo, no debía confundirse "igualdad política" con "igualdad absoluta". En la relación entre ricos y pobres se trataba del establecimiento de una igualdad respecto a los actos que tuvieran que ver con la moral, con "sus propios vicios y virtudes". ${ }^{34}$

Seguramente el padre Cantón conoció este documento que dictaba las reglas a seguir por los fieles ante las medidas derivadas del restablecimiento de la Constitución de 1812. Para los jesuitas y religiosos de otras congregaciones el problema se conectaba con una de las implicaciones de dicho restablecimiento: la anulación de su propio restablecimiento. Esta situación de desconcierto se transmite en la carta enviada por el padre Cantón - sustituto en el cargo del padre Castañiza, fallecido en 1817- el 23 de agosto de 1820: "No sabemos (debido al golpe de timón) cuál será nuestra suerte. VR la sabrá antes que nosotros. ¡Ojalá y nos volviéramos a juntar! Dichosos los Rusos que padecen por la justicia". ${ }^{35}$ En esa situación el futuro de la institución quedaba a merced de las decisiones de los diputados en las Cortes. De ello eran conscientes las autoridades jesuíticas en uno y otro lado del Atlántico. ${ }^{36}$ Cantón, por lo pronto,

\footnotetext{
${ }^{34}$ AHAM, Pedro Fonte, "Edicto", 18 de julio de 1820.

35 Carta del padre Cantón al padre Juan Fermín Martínez del 23 de agosto de 1820. AHPM/FGD, XXII-11.

${ }^{36}$ Carta del padre Cantón al padre Juan Francisco Arrieta del 5 de julio. AHPM, GD, XX-11.
} 
suspendió cualquier decisión hasta no saber "la resolución de las Cortes".37

Las Cortes se reunieron en Madrid el 9 de julio de 1820 con los diputados electos de cada una de las circunscripciones del Imperio. El historiador jesuita Decorme nos dice al respecto que algunos leales al "plan de la Profesa" (que retomaremos más adelante), vinculado supuestamente con Iturbide, no llegaron a embarcarse, y otros arribaron cuando ya se habían tomado las decisiones importantes, como la relacionada con la supresión de los jesuitas. Entre los diputados a favor de la medida menciona a Ramos Arizpe, Fagoaga, Michelena, Cortázar y Montoya, a los que se sumaron después elementos más moderados identificados con la política jansenista. ${ }^{38}$ Fue por medio de la Gaceta del gobierno de Madrid de 15 de agosto de 1820 que los jesuitas mexicanos se enteraron de que el Congreso de las Cortes había "decretado otra segunda extinción de los jesuitas”, oficializada el 17 de agosto de $1820 .{ }^{39}$

37 Carta del padre Cantón al padre Arrieta del 13 de octubre. AHPM, GD, XX-11.

38 Decorme, Historia de la Compañía de Jesús, p. 184. En la versión de Dávila y retomada por Decorme, parecería que la decisión de la supresión estuvo inspirada en una disputa jurídica entre los canónigos de San Isidro en Madrid y la decisión de Fernando VII de restituir a los jesuitas dicho local como colegio imperial. En esta interpretación se sugiere que con base en un problema estrictamente local "madrileño" se tomó una decisión que afectaba mucho más a las regiones americanas donde había jesuitas.

39 "Decreto. Supresión de la compañía de Jesús, y restitución al cabildo de la iglesia de S. Isidro de esta corte, de los derechos y funciones que obtuvo al tiempo de su creación. Agosto 17 de 1820”, en Legislación mexicana o colección completa de las disposiciones legislativas expedidas desde la independencia de la República. 
A partir de la publicación del decreto de expulsión se conocen especialmente dos reacciones en forma de representaciones en defensa de los jesuitas. La primera es del sonorense Juan Miguel Riesgo, Justo Reclamo de la América a las cortes de la nación, ${ }^{40}$ contraria a la extinción en la que pone de relieve los grandes beneficios que produjeron los jesuitas, sobre todo en la educación. La segunda es una larga disertación acerca de por qué los jesuitas no debían ser suprimidos, publicada por un grupo de ciudadanos poblanos a fines de $1820 .^{41} \mathrm{Un}$ aspecto sustantivo que hace diferentes esta clase de reacciones en relación con las de la expulsión de 1767 es que aparecen enmarcadas por la libertad de prensa, por la que en teoría todo ciudadano tiene el mismo derecho para opinar y debatir sobre las cuestiones públicas. ${ }^{42}$

En el escrito del sonorense Riesgo se destaca a los jesuitas como educadores, humanistas, misioneros, exploradores y fundadores de poblaciones: "Multitud de gentiles reducidos en las provincias de Sonora, Sinaloa, y Californias" que

40 Riesgo, Justo Reclamo de la América a las cortes de la nación, 28 de octubre, 1820. Se encuentra en el AHPM, GD-XXIII-3. Riesgo fue el primer gobernador constitucional del estado de Sonora, y seguramente coautor de la Memoria sobre las proporciones naturales de las provincias internas occidentales, 1822. Esta Memoria aparece firmada el $1^{\circ}$ de julio de 1822 por Riesgo, Salvador Porras, Francisco Velasco y Manuel José de Zuloaga. Es probable que Riesgo fuese diputado americano en las Cortes de España en 1811. Es firmante junto con otros notables como Dionisio Inca Yupanqui, José María Couto, José Miguel Guridi y Alcocer, Miguel Lastiri, Antonio Joaquín Pérez, Miguel Ramos Arizpe, etc., de la Representación de la Diputación Americana a las Cortes de España, en 1ำ de Agosto de 1811.

${ }_{41}$ "Defensa de los padres jesuitas, por Los Poblanos".

42 Algunas de las reacciones en el contexto de la expulsión se encuentran en Torres Puga, Opinión pública, pp. 43-122. 
dieron paso a la consolidación de la Monarquía española en zonas fronterizas, sin dejar fuera su labor en el campo de "las ciencias y de las artes: muchos españoles fueron sabios bajo su dirección y enseñanza, y de la misma recibieron doctrinas para ser ciudadanos útiles, buenos padres de familia y católicos verdaderos". De ahí la preocupación de que "el augusto Congreso de las Cortes haya decretado otra segunda extinción de los Jesuitas". Por esa razón solicita la revisión y suspensión del decreto hasta no garantizar la presencia de los diputados americanos que no pudieron llegar a tiempo. Se afirma además que de ninguna manera los jesuitas representaban una amenaza para la Constitución. No se entiende en consecuencia la campaña desatada en su contra por medio de "tantos infamatorios libelos" hecha por "muchos aduladores detestables y otros escritores [...]". Pone toda su confianza en sus "representantes", jefes políticos y autoridades eclesiásticas para que se suspenda la medida tomada. ${ }^{43}$ De ahí emerge la inquietud acerca de si los diputados ante las Cortes representaban o no los intereses de las mayorías, o si más bien éstos estaban sujetos a otra clase de intereses particulares o corporativos. Además, en torno a la cuestión de los jesuitas, se planteaba que los conflictos de la Península no eran idénticos a los americanos.

La segunda representación toma en cuenta la de Riesgo, pero proviene de Puebla, un lugar en el que los jesuitas tienen y habían tenido mayor presencia. ${ }^{44}$ Tal como se refleja

${ }_{43}$ Riesgo, Justo Reclamo.

${ }^{44}$ DÁvila, Historia, pp. 234-235. Después de la expulsión en 1767 se sabe que la presencia jesuítica pudo haberse mantenido de diversas maneras. Al respecto, el interesante ensayo de Bernabeu, "El vacío habitado", pp. 1261-1303. 
en la correspondencia del padre Cantón, el tema de la representatividad y legitimidad de los diputados americanos en las Cortes era también la preocupación fundamental, que incluía la cuestión de la igualdad y equidad en cuanto al número de representantes por cada continente.$^{45}$ En sus cálculos, por sólo 30 americanos participaban 150 miembros peninsulares. Además se puntualizaba que los intereses de los "americanos" no coincidían del todo con los de los "peninsulares". Eso se veía, por ejemplo, cuando se discutía sobre fomento y adelantamiento de fábricas de algodones y sedas en crisis, frente a los apoyos que recibían los catalanes, valencianos, murcianos, malagueños y otros. "Lo mismo debe afirmarse con respecto a las fábricas de tejidos de lanas de las dos Castillas, del lino de Galicia y de los vinos de las Andalucías". Aun cuando los representantes americanos escribieran y discutieran como si fueran unos "Demóstenes" en el estrado, desde el principio estaban en desventaja numérica. Además, estaban de por medio las tentaciones desplegadas allá a sus representantes, sabiendo que no todos eran "héroes para prescindir de los intereses personales y de los respetos humanos, los que casi nunca son compatibles con el puesto de la representación nacional: de aquí es que [tengan] un prudente recelo de que la firmeza pueda claudicar atendida la fragilidad de los hijos de Adán”. Incluso los americanos residentes en España habían dejado de representar a los americanos porque habían dejado de ser "vecinos", pues ya no valía el solo hecho de haber

\footnotetext{
45 "Tres de las provincias de Europa y tres de la de ultramar, y el séptimo saldrá por suerte entre un diputado europeo y otro de ultramar. Por cada 70 mil almas se nombra un diputado, siendo menos las de las Américas no le cabe tanto número de representantes." Carta del padre Cantón, en AHPM, GD, XXIII-4.
} 
nacido acá. Así la falta de representatividad era "un defecto insanable para la legislación de ultramar, que intentará darse en las Cortes de este año [...]". 46

Respecto a la defensa de los jesuitas salta a la vista también que entre americanos y peninsulares existía otra clase de reclamaciones que seguramente tendrán su parte en los sucesos de 1821. Los jesuitas y sus defensores argumentaban no sentirse representados por quienes expidieron un decreto de extinción que se hacía extensivo a otras congregaciones hospitalarias como las de los betlemitas, juaninos e hipólitos. Establecimientos, se dice, que eran tan necesarios y útiles a "estos países". Consideraban que llevar una medida antipopular "contra la opinión nacional” podía ser muy peligroso y arriesgado, expuesto "a causar tumultos, porque como el pueblo no es una comunidad religiosa habituada o acostumbrada a sufrir la estrechez de la obediencia, se resiente mucho de la violencia que se hace a sus deseos, porque conoce que se obra prácticamente contra la voluntad general, y si no que lo digan cuantos leyeren estos nuestros sentimientos”. Así, la voluntad de las Cortes no necesariamente representaba la "voluntad de la Nación”, y era en ésta donde residía propiamente "la Soberanía", "de cuyo ejercicio todavía no [tenía] una idea cabal y clara" ${ }^{47}$ Conforme la decisión se alejaba de las expectativas americanas, iría creciendo la animadversión y caricaturización entre los dos bandos, en la que ya no sólo

46 "Defensa de los padres jesuitas". En nota a pie se destaca de nuevo el argumento sobre los 30 diputados a las Cortes extraordinarias, de los cuales 29 hicieron representaciones a favor del restablecimiento de los jesuitas en las sesiones de 16 y 31 de diciembre de 1810. También en AHPM, GD, XXIII-3.

47 "Defensa de los padres jesuitas". 
estaba la cuestión jesuítica, sino también la de los “americanos”. De un lado, la secta de los enemigos de los jesuitas cuyo "patriarca principal” era Voltaire, y del otro, los amantes de la "Religión Cristiana”.

La comunicación de los poblanos en principio estaba dirigida al virrey Apodaca, "Gefe superior político del reino", a quien consideraban ser un individuo piadoso, no inclinado al servilismo, de trato afable y generoso. Asimismo los poblanos se consideraban no ser aduladores ni tampoco dados a infamar; para ellos un aragonés era igual que un mexicano. Aunque "malos cristianos", se declaraban "buenos católicos”. El comunicado estaba firmado por 1427 individuos seglares, no clericales, "en el ejercicio de los derechos de ciudadanos”, y que agrupaba representantes de todas las clases sociales: comerciantes, milicianos, jefes políticos, empleados, letrados, artesanos y gobernadores de las repúblicas de indios. ${ }^{48}$

De la elaboración de esta representación poblana disponemos del testimonio de uno de los jesuitas de Puebla que escribió al padre provincial para ponerlo al tanto del apoyo recibido por los poblanos. El 15 de diciembre de ese año de 1820 le comunica que la iniciativa había surgido de un "europeo sin letras”, quien se ocupó del trabajo de edición hasta entrada la noche. Realmente, añade, él mismo no esperaba una respuesta tan amplia después de correrse la voz, destacando la generosidad de los notarios (escribanos) que gratuitamente certificaron el documento. Además de la publicación, había promovido dos novenarios de misas cantadas en la

48 "Defensa", rubricada por Ignacio Reyes Mendizábal y Pliego, Ignacio de Urrutia, José María Torres. Véase también, Hamnett, Revolución y contrarrevolución, p. 305. 
iglesia de Santa Rosa “por nuestra Conservación”. Y para el día 18 se había programado en la iglesia jesuita una misa para celebrar el aniversario de su llegada. Además le comentó que se dirigiría personalmente a los dos jefes, eclesiástico y civil, para convencerlos de la causa jesuítica. Todo se había hecho y se haría tomando todas las precauciones posibles, tratando de no provocar o insultar a las autoridades del gobierno. El promotor de la causa le prometió personalmente que evitaría que el pueblo tomara las armas para protestar. Habría que tener cuidado, por ejemplo, con el repique de las campanas para que no se hiciese demasiado ruido en el "vecindario" al momento de su salida, sin que fuera difícil que estuvieran "comprometidos los serenos, los guardas de garitas y algún campanero de la Parroquia u otras Iglesias". Como medida de precaución, añade el jesuita, estaría pensando en tomar el camino de Acolman para dirigirse a México, etcétera. ${ }^{49}$

Sin duda, la comunicación da idea del temor a que se desataran "conmociones populares" al tiempo que se intentaba mantener la "obediencia al legítimo gobierno" según lo establecido por el arzobispo Fonte. Pero también se manifiesta el grado de simpatía que podían tener los jesuitas en el medio en el que desempeñaban sus actividades.

No obstante, la orden de exclaustración tan anunciada y temida finalmente llegaría a principios de enero de 1821. Por bando del virrey Apodaca se hizo público el mandato expedido el 16 de septiembre de 1820, fechado en Madrid dos días después, en el que se daba a conocer el decreto de las Cortes del 17 de agosto de 1820, por el que se suprimía la Compa-

${ }^{49}$ Carta al padre Cantón del 15 de diciembre de 1820, AHPM, FD, XXIII-5. 
ñía de Jesús en toda la Monarquía española, lo cual implicaba el regreso de todas las temporalidades o bienes de los jesuitas al crédito público. ${ }^{50}$ En ese sentido, la publicación de esta medida por la autoridad máxima del virreinato, el 23 de enero de 1821, hará efectiva la nueva supresión de los jesuitas.

Según se nos cuenta, ese día los jesuitas salieron e hicieron entrega del Colegio Máximo de San Pedro y San Pablo y del seminario de San Ildefonso al rector nombrado por el virrey, doctor Simón de la Garza. En relación con el modo como se efectuó el acto se tienen dos versiones, la de Carlos María Bustamante y la de Mariano Dávila. La diferencia radica en que mientras en la primera se alude a haberse realizado con violencia, en la segunda, la operación se hizo en forma pacífica y civilizada. Bustamante dramatiza, quizás recordando los relatos de la expulsión de 1767, mientras Dávila se respalda en el hecho de haber sido testigo de lo ocurrido, ya que como novicio se encontraba en el Colegio de San Pedro y San Pablo. Testifica que no intervino la fuerza armada. ${ }^{51} \mathrm{Al}$ día siguiente el provincial fue recibido en el Hospicio de San Nicolás de los agustinos descalzos. Por su parte los jesuitas del Colegio de Puebla salieron para México el mismo día 23 de enero. El Colegio de San Gregorio fue entregado desde la noche del 22 al presbítero Juan Francisco Calzada, su antiguo capellán. Un mes después regresaron los jesuitas de Durango. En total el número de los jesuitas exclaustrados de los tres colegios era de 38 , tomando en cuenta el fallecimiento del padre Márquez: 17 sacerdotes: 5 profesos de cuatro votos,

50 Ruiz de Apodaca, Bando del virrey JRA.

51 Una relación pormenorizada en Dávila y Arrillaga, Continuación, pp. 236-239. 
7 novicios que habían hecho los primeros votos o del bienio y 5 que estaban todavía en el noviciado; 8 escolares de los cuales 3 eran aún novicios y los demás hermanos coadjutores, de los cuales sólo tres habían completado la primera probación. ${ }^{52}$

En la relación de Dávila y en la de Bustamante se conectan los sucesos de los días 22 y 23 de enero con los del 2 de febrero de 1821, día en el que el coronel Agustín de Iturbide, amparado en el Plan de Iguala, proclamó la independencia de la Nueva España. Entre las razones del levantamiento estaba supuestamente "la indignación que a todos los sensatos había causado la supresión de las religiones hospitalarias y de la Compañía de Jesús, por cuya razón todos conjeturaban que apenas el Sr. Iturbide pondría victorioso el pie en México, esas órdenes serían restablecidas". ${ }^{53}$

\section{EL AÑO DE LA INDEPENDENCIA}

Poco antes de morir, el historiador Lucas Alamán difundió la versión de las reuniones que tuvieron lugar en la iglesia de la Profesa (propiedad de los jesuitas hasta antes de la expulsión de 1767 y que luego pasó a manos de los oratorianos) en las que presuntamente se fraguó (se "conspiró") el plan de independencia. En ese local se reunirían a partir del mes de noviembre de 1820 un grupo de notables civiles y eclesiásticos encabezados por el canónigo Matías de Monteagudo, el mismo que había acaudillado la revuelta contra Iturrigaray en 1808. Muchos de ellos integrarían después la Regencia o Junta

52 Catalogus.

53 Dávila y Arrillaga, Los jesuitas en México, p. 240. Historia de la Compañía de Jesús, III, 1841-1842, p. 314. 
Gubernativa del Imperio de Iturbide. No es difícil imaginar que este grupo gozaría de las simpatías del Marqués de Castañiza, obispo de Durango y amigo de los jesuitas. Uno de los temas que discutirían en aquellas reuniones se relacionaría con las decisiones de las Cortes respecto a la supresión de las órdenes religiosas y al fuero eclesiástico. Por tanto, el restablecimiento de la Constitución liberal de Cádiz sería valorado como una gran amenaza para la defensa de la "Religión”. Resultado de dichos encuentros sería el entrar en contacto con el coronel Iturbide, miembro del ejército realista, y se proyectaría lo que contendría en esencia el Plan de Iguala, manifiesto general enfocado a romper los lazos políticos con España por haber quedado ésta en poder de los liberales. Por eso, en principio se trataría de restaurar una vez más la monarquía presidida por Fernando VII, pero con la posibilidad de que el trono imperial esta vez se trasladara a México, donde encontraría sus más leales vasallos, y así dar continuidad y legitimidad a la casa de los Borbones. Tal sería el plan original que, como sabemos, tomaría otro sesgo al recibir la negativa del monarca al ofrecimiento, $\mathrm{y}$ verse obligado Iturbide circunstancialmente a proclamarse como monarca imperial mexicano. Hasta aquí sería la versión de Alamán suscrita en su publicación de 1852, avalada, dice él, por lo que habría escuchado de boca del jurista José Bermúdez Zozaya y otro conocido (el Sr. Edoardo), ambos conocedores directa o indirectamente de aquellos acontecimientos. Así, basado en estos testimonios se hablaría de la "conspiración de la Profesa”, versión que a finales del siglo xix se encontraba ya canonizada por la historiografía oficial y que seguiría su travesía exitosa a lo largo del siglo $\mathrm{xx} .{ }^{54}$

${ }^{54}$ Por ejemplo, García Cubas, Geografía e historia del Distrito Federal, 
Ahora bien, Alamán no era ingenuo al advertir enseguida a sus lectores que en absoluto era fácil fijar con toda certeza la verdad de lo que realmente sucedió, debido a que los mismos actores se habían guardado de hacer públicos sus "secretos", o bien porque habían hecho desaparecer documentación comprometedora. Además estaba convencido - y en eso era indiscutiblemente moderno - de que lo que en general ocurría no siempre sucedía de acuerdo con los planes e intenciones proyectados por los actores. Con lo cual él mismo abría la duda acerca del modo como pudo haberse presentado la conexión entre la nueva “injusticia” cometida contra los jesuitas y la consumación de la independencia mexicana. ${ }^{55}$

Desde otro ángulo, podría entenderse también la versión difundida por cronistas contemporáneos, en el sentido de que la supresión de la Compañía de Jesús en 1820, respaldada en la Constitución de 1812, fue uno de los motivos principales - como reacción al decreto en defensa de los jesuitas - que impulsaron a muchos de sus protagonistas a proclamar la independencia de México. En tal sentido los jesuitas exclaustrados podrían haber visto favorablemente la iniciativa de Iturbide alrededor del Plan de Iguala (24 de febrero de 1821) y los Tratados de Córdoba (24 de agosto de 1821). De hecho, entre los artículos del Plan había alguno que establecía la conservación del "clero secular y regular" en "todas

al describir el edificio de la Profesa incluye una mención de una reunión de "varios individuos" "en el aposento del Dr. Monteagudo [1820] quienes trataban de impedir la publicación de la Constitución española, etc.”, p. 58. Esto mismo también es mencionado en la relación del historiador jesuita Olmedo, Manual de historia, p. 264.

55 Alamán, Historia de Méjico, pp. 40-64. 
sus fuerzas y preeminencias". ${ }^{56}$ No obstante, en la apuesta jesuítica por la independencia podría haber un aspecto paradójico: el grupo que ahora apostaba por el restablecimiento era el mismo que se había opuesto a la autoridad legítima del virrey en los sucesos de 1808. Sólo que en vez de defender al monarca por haber sido secuestrado por los franceses, ahora se le veía secuestrado por las fuerzas liberales españolas "afrancesadas". 57

Sea lo que sea, para los jesuitas estos meses estuvieron marcados por la incertidumbre y el desconcierto. Es bastante probable que los jesuitas - ahora fuera del orden legal y sin posibilidad de vivir en comunidad - apostaran por la independencia de España en la medida en que Madrid había quedado bajo el control de los liberales. Con esta preferencia esperarían poder obtener un reconocimiento por parte del nuevo gobierno, situado a una relativa distancia de los liberales, defensores de la Constitución de Cádiz, pero con la voluntad al mismo tiempo de establecer por primera vez un régimen político propiamente "mexicano". No deja de ser curioso que fueran ellos los hacedores de la independencia, en alianza con las fuerzas que quedaban de los insurgentes de 1810, y no propiamente los liberales. Dentro de este entramado político los jesuitas ponían su esperanza en su pronto restablecimiento apoyados en uno de los artículos del "reglamento provisional político del Imperio Mexicano" del 18 de diciembre de 1821. Tras declarar la abolición de la Constitución española y que los súbditos de la nueva nación

56 En García Diaz, Independencia nacional, IV, pp. 148, 150. Véase también, Arenal, "El Plan de Iguala”, pp. 73-91.

57 Véase BREÑA, El primer liberalismo español, pp. 446-447. 
profesarán “la religión católica, apostólica, romana con exclusión de toda otra”, se reiteraba lo suscrito en el Plan de Iguala: "El clero secular y regular, será conservado en todos sus fueros y preeminencias conforme al artículo 14 del plan de Iguala”. Por tanto, "para que las órdenes de jesuitas y hospitalarios puedan llenar en procomunal los importantes fines de su institución, el Gobierno las restablecerá en aquellos lugares del Imperio en que estaban puestas, y en los demás en que sean convenientes, y los pueblos no lo repugnen con fundamento", etcétera. ${ }^{58}$

TRAS LA INDEPENDENCIA

No deja de ser extraño lo que vino después, cuando los jesuitas enfrentaron grandes dificultades para obtener su restablecimiento. Bajo el Imperio de Iturbide la decisión no recaía más en las Cortes españolas sino en la Junta Gubernativa del Imperio mexicano reunida a partir de noviembre de 1821. La sección de la Junta encargada de los asuntos eclesiásticos estaba formada, entre otros, por los bachilleres José Manuel Sartorio, Francisco Severo Maldonado y José Manuel Monteagudo, y presidida por el canónigo Miguel Guridi y Alcocer. Sin embargo, tras una discusión acalorada en las sesiones del 13 al 15 de noviembre, los elegidos decidieron posponer la resolución acerca de su restablecimiento al declararla un asunto no urgente a revisar. Esta resolución no se modificaría aun cuando aparecieron signos de inconformidad por parte de un sector de la ciudadanía.

58 "Reglamento provisional político del Imperio Mexicano", 2 de noviembre de 1822 . 
A pesar de que los ahora exjesuitas podían moverse entre amigos y potenciales simpatizantes y de la independencia de España, al revisar las Actas de las sesiones del Congreso se observa la intención de demorar la resolución; al parecer la razón de esto es que continuaba vigente la decisión establecida durante el régimen político anterior al de la independencia. De esta anomalía se da cuenta en una protesta de dos ciudadanos poblanos que hicieron llegar a la sesión $5^{\text {a }}$ del 16 de marzo de 1822. Antonio Bandini y Francisco Ponce enviaron una representación que aquel vecindario hacía al Congreso Constituyente sobre la restitución de los jesuitas, en la que los diputados acordaron simplemente contestar que se daban por enterados. ${ }^{59}$ Casi al mismo tiempo se publicó una réplica contraria a dicha representación llegada desde Veracruz. ${ }^{60}$ Estas dos expresiones son sólo algunas señales de la aparición en la prensa de 1821 y 1822 de una copiosa literatura jesuítica y antijesuítica, en la cual sobresale, entre otros, Fernández de Lizardi y en la que no podemos extendernos ahora. ${ }^{61}$

59 En Noriega, La Diputación Provincial de México, pp. 166-167. BanDINI y PONCE, Contestación dada por algunas corporaciones.

60 "Impugnación de las calumnias e imposturas inventadas contra la Compañía de Jesús”, Biblioteca Lerdo de Tejada (BMLT). Fueron publicadas en el Diario de Veracruz, "Sobre el asunto desagradable de los jesuitas. En respuesta a Francisco Javier Ponce de Puebla”, n. 127-130 y 140141 y rubricado por C. T. S. el 5 de enero de 1821. Ahí los jesuitas aparecen como una suerte de masonería blanca análoga a la orden de los templarios. ${ }^{61}$ Algunos títulos a manera de ejemplo. Riasa, "Incitativo sobre la restitución de las religiones suprimidas", 1821 (BN/CL); La corneta. "Cornetaso a los cerviles”, Diario Constitucional, 1821, p. 234; Fernández DE LizARDI, "Reflexiones interesantes sobre la carta que se dice dirigida por N. SS. P. el señor pío VII, al señor don Fernando VII”, 1821, 12 pp. (BN/CL). En Querétaro hubo también una Representación suscrita por una larga lista de firmantes en defensa de la restauración. 
A partir de dicha "irresolución" en el Congreso se puede decir que se reinicia propiamente una confrontación periodística entre los amigos y los detractores de los jesuitas. Una lucha entre quienes defendían, por ejemplo, que con los jesuitas la Iglesia perdía su "ojo lúcido" y desaparecía el muro de contención contra la irreligiosidad creciente, ${ }^{62}$ por lo cual se requería su restablecimiento ${ }^{63}$ quienes los veían como representantes del "retroceso", ${ }^{64}$ haciendo publicar materiales anteriores a la expulsión de 1767, cuyo número se incrementará a partir de la década de 1830.

$\mathrm{Al}$ incluir el diario de las sesiones del Congreso, en la versión de Dávila se nos dice que fueron los “ilustrados" los que se opusieron al restablecimiento de los jesuitas, no obstante el deseo de "la nación entera". En su opinión eran tres los factores que explicarían el fracaso de la resolución: primero, que los amigos de los jesuitas no estaban acostumbrados

62 "Defensa de jesuitas", 31 de octubre de 1822 (BN/CL).

${ }^{63}$ Fernández de Lara, "Retrato de los jesuitas, por el cura de Tepeyanco, pide el establecimiento de los jesuitas", 16 de julio de 1822.

${ }^{64}$ Por ejemplo, en la Gaceta diaria de México (25 oct. 1825) se lee que en Inglaterra no había jesuitas que impusieran "restricciones mentales", que en cuestiones de hacienda "el jesuitismo" era "un ausiliar [sic] pernicioso". Inglaterra era un país en el que no se hablaba todo el tiempo de religión, "pero donde sin jesuitas, sin monges, sin un inmenso aparato religioso, tiene el culto de la buena fe tantos sacerdotes como habitantes" y "excelente educación moral"; o en El Sol (2 jul. 1827), se escribe que a causa de los ministros religiosos "la libertad de imprenta" había recibido golpes funestos. Y añadía: "el feudalismo no renace: los jesuitas se restablecen, y el veneno corrosivo de la monarquía va concluyendo con los débiles restos del gobierno representativo". En El Sol (16 oct. 1827) se reporta la sesión de la Cámara de Senadores del 2 de octubre en la que se hizo mención de los jesuitas al explicar las razones de su expulsión. En El Sol (13 mayo 1828), en una nota relacionada con Francia los jesuitas aparecen como fanáticos y supersticiosos. 
a las "fórmulas parlamentarias, sistema enteramente nuevo entre los mexicanos” y, así, sus enemigos “se valieron de esa impericia para enredarlos en sus mismos hilos, desnaturalizar la cuestión y obtener el triunfo de sus ideas"; la segunda, que en la sesión del día 13 de noviembre la votación quedó empatada, y con todo se insistió en la negativa; fue una votación irregular, fraudulenta. La tercera razón es que el partido antijesuita retornó a los viejos argumentos borbones del relajamiento de los regulares. Y concluye: "No puede negarse que el ardid fue ingenioso, y mucho más con otras travesurillas parlamentarias que ocurrieron $[\ldots]$ ”. ${ }^{65}$

Ahora bien, conforme se enfriaba la solicitud de reinstalación y el Imperio de Iturbide se desplomaba por la asonada de Antonio López de Santa Anna dando lugar al federalismo republicano de $1824,{ }^{66}$ el tema de los jesuitas se fue desviando crecientemente hacia la cuestión de la venta y subasta de las temporalidades o bienes y edificios del instituto religioso, como los colegios y misiones en diferentes capitales de los estados como Chihuahua, Querétaro, San Luis Potosí, Puebla, Guadalajara y las Californias. ${ }^{67}$ La llegada al gobierno del

65 Dávila y Arrillaga, Continuación, pp. 246-247.

66 La instauración del nuevo régimen significa en buena medida el regreso de los "vencidos" en los hechos de 1808, al menos si se considera la presencia del primer presidente de la República, Guadalupe Victoria, antiguo alumno de San Ildefonso y disidente insurgente a partir de 1811. Véase GuedeA, En busca de un gobierno alterno.

${ }^{67}$ Véase por ejemplo, Águila Mexicana (13 mayo 1824), p. 4; El Sol (27 oct. 1824), p. 1; Gaceta del Supremo Gobierno de la Federación Mexicana (13 ene. 1825), p. 2.; El Sol (5 mar. 1827), p. 1; El Sol (19 mar. 1827); El Sol (17 feb. 1828), p. 1. El Sol notifica que el presidente, por determinación del Congreso, dirige el decreto al secretario de Hacienda para que ceda al estado de Chihuahua el colegio que fue de los jesuitas en esa capital, "con tal de que lo destine a la enseñanza pública” y construya de su 
bando opositor al de Monteagudo e Iturbide - con reminiscencias de los hechos de 1808 desencadenantes de la rebelión de Hidalgo y fray Servando - fue valorada en 1824 como una "segunda revolución", surgida en 1820 con el restablecimiento de la Constitución de $1812 .{ }^{68}$

Como se mencionó, Iturbide no deja de ser también una figura paradójica. Llega al trono casi por accidente. Ofrecido el trono a Fernando VII y rechazado por éste, se abrió la vía para buscar una solución al conflicto, no a la "española" sino a la "mexicana". En ese sentido la independencia fue un regalo inesperado que dejó a los jesuitas en una encrucijada. Ya con Iturbide esperaban conseguir su rehabilitación con la anulación de la medida derivada de la Constitución de Cádiz. Sin embargo, al no depender ya la decisión exclusivamente de Iturbide, los jesuitas también quedaron al arbitrio de los parlamentarios. Pero Iturbide no sólo no dio entrada al restablecimiento jesuítico sino que tampoco lo hizo en relación con el Patronato Indiano. Este segundo aspecto, como se sabe, marcará en buena medida el futuro de las relaciones conflictivas entre la Iglesia y el Estado. ${ }^{69}$

cuenta un hospital militar. Dada en Palacio de gobierno el 7 de febrero de 1828. Incluso El Sol (22 mayo 1830), pp. 1-2, publica la continuación de un discurso pronunciado por el señor Monjardín en el Senado. Tiene que ver con el problema de la herencia de la señora Castañiza, la hermana de Juan Francisco Marqués de Castañiza: "La Castañiza falleció bajo el testamento por el que nombró herederos, no colectiva, etc.". En esa discusión intervino también Lucas Alamán.

${ }^{68}$ Mora, “Introducción”. Véase también Zermeño, “El concepto Revolución, 1780-1870”.

${ }^{69}$ Véase Costeloe, Church and State in Independent Mexico. También Casillas, "Del Patronato al nombramiento de obispos", pp. 83-108 y Aguilera Murguía, "La Arquidiócesis de México”, pp. 33-58. 
En efecto, el ahora exjesuita Basilio M. Arrillaga, que había regresado de Puebla a México después del anuncio de la extinción en 1821, se puso a las órdenes del arzobispo Fonte y, ya como miembro de la Junta Eclesiástica, el 24 de noviembre de 1821 cuestionaría a la Regencia del Imperio haber suprimido el Patronato Eclesiástico, ${ }^{70}$ que influía directamente en las relaciones entre la nueva entidad política y $\operatorname{Roma}^{71} \mathrm{y}$ afectaba también a la posibilidad del restablecimiento jesuítico.

Uno de los artífices de este nuevo frente en disputa - antagonista de Arrillaga en el futuro - fue el antiguo estudiante y colaborador del Colegio de San Ildefonso, José María Luis Mora. Al referirse a la situación del enfrentamiento entre la Iglesia y el Estado de 1825 adoptó una posición galicana en el sentido de favorecer la formación de una iglesia mexicana que restara poder económico a Roma. Sostenía que la Iglesia había mezclado en exceso los intereses espirituales con los temporales. Además, so pretexto de la religión se había inmiscuido en los asuntos internos pertenecientes a las naciones. En esas relaciones México tradicionalmente había salido perdiendo. Con la independencia su primer error fue nombrar al obispo Francisco Pablo Vázquez ministro plenipotenciario en Roma, un eclesiástico a todas luces favorable a las pretensiones de la curia romana, y por tanto dispuesto a sacrificar

70 Es conocido el texto de Arrillaga publicado más tarde, cuando el gobierno esté en manos de la oposición. Arrillaga, Examen crítico.

${ }_{71}$ Sobre las dificultades entre ambas potestades en la nueva situación se puede consultar Connaughton, "La Secretaría de Justicia y Negocios Eclesiásticos”, pp. 127-147. 
los intereses nacionales. ${ }^{72}$ Ya en Roma, Vázquez, por su parte, habría encontrado en el exjesuita Ildefonso José Peña (17981869) - veracruzano y novicio jesuita en 1816 - a su confidente y aliado.

Fue en ese contexto que el papa León XII expidió una encíclica en 1825 en la que exhortaba a las naciones independientes a regresar al yugo de Fernando VII, pieza diplomático religiosa controvertida que naturalmente generaría reacciones encontradas. ${ }^{73}$ En ese sentido el litigio en torno al restablecimiento de la orden ignaciana crecientemente pasará también por el filtro de la creación de los nuevos nacionalismos, enmarcados por la lucha entre las luces de la Ilustración y las sombras del oscurantismo o del fanatismo religioso.

\section{LA SITUACIÓN DE LOS (AHORA) “EXJESUITAS”}

La nueva situación política significó para los jesuitas, en primer lugar, no poder congregarse más en vida comunitaria. Es decir, vivir en una suerte de diáspora y dispersión interior de sus miembros, sólo conectados mediante la comunicación

72 Mora, México y sus revoluciones, I, p. 323.

${ }^{73}$ Mora, México y sus revoluciones, I, pp. 324-325. Sobre Vázquez en Europa, véase la correspondencia entre Peña y el arzobispo Fonte en Gómez Ciriza, México ante la diplomacia vaticana, pp. 139-152. Sobre la buena relación de los jesuitas con el obispo Vázquez, la carta del padre Pedro Cantón al general Luis Fortis de 4 de mayo de 1825. AHPM, Correspondencia de la Provincia, 1816-1853/1-II, 4. También circuló el escrito de fray Servando crítico de la infalibilidad papal, Discurso del Dr. Servando Teresa de Mier sobre la encíclica del Papa León XII. El Breve Pontificio Etsi iam dico ("aun cuando ya hace tiempo") al Episcopado de América es del 10 de febrero de 1825 y fue difundido en la Gaceta de Madrid. 
con el padre provincial, Pedro Cantón. Por uno de sus informes enviados a Roma sabemos, por ejemplo, que en 1826 había 18 jesuitas activos, algunos ya mayores como los padres Plaza y Lyon, y otros más jóvenes de la "nueva Compañía", y sólo un hermano coadjutor. ${ }^{74}$ De este número se puede inferir que tras la extinción pudo haber algunos que decidieron no continuar. En segundo lugar, que después de 1821 y tras la ocupación de sus "temporalidades" ${ }^{75}$ por el gobierno, cada uno de sus miembros tuvo que arreglárselas para hacerse de fondos por medio de algunas capellanías como clérigos seculares. Debido a esta situación anómala, al parecer los ahora exjesuitas recibirían "licencias amplias" para sus gastos y actividades, aunque guardando los votos religiosos y las reglas básicas de la institución jesuítica. Sin embargo, se presentarían algunos casos excepcionales, como el del padre Blas Perea, ecónomo de la provincia, que se dedicaría de lleno a la labranza de la tierra para apoyar la economía de su parentela. $^{76}$

En los siguientes años habrá algunos exjesuitas que tendrán bastante notoriedad pública, como los padres Arrillaga y Olaguíbel en la ciudad de México, y Gutiérrez del Corral

${ }_{74}$ Padres Pedro Cantón, Ignacio Amaya, Ignacio Plaza, Ignacio Lerdo, Francisco Mendizábal, Ignacio Lyon, Lorenzo Lizárraga, Joaquín Martel, José Rivas, Miguel Martel, Cipriano Montúfar, Basilio Arrillaga, José Rafael Olaguíbel, Luis Traslosheros, Blas Perea, Luis Gutiérrez del Corral, Juan María Corona y Francisco Ravaná. AHPM. Correspondencia 1816-1853, 1/II/1826.

75 Se trataría, por ejemplo, de algunas fincas urbanas o haciendas como la de San José de Acolman o la de la Compañía junto a Chalco pertenecientes al Colegio de San Gregorio.

${ }^{76}$ Carta del padre Cantón al padre general Juan Roothaan, 25 de agosto de 1830. AHPM, Correspondencia de la Provincia, 1816-1853-1-II, 16. 
en Puebla, así como Francisco Mendizábal - licenciado en cánones por la Universidad de México y abogado de la Real Audiencia, que en 1818 tenía 32 años-, que sucederá a partir de 1834 al padre Cantón como provincial. Otros se situarán en Roma, como el mencionado padre Peña y el padre Ignacio Lerdo de Tejada, quien había hecho sus primeros votos el 3 de enero de 1819 , siendo ya doctor en teología por la Universidad de Granada y experto en lengua griega. En algún momento un par de exjesuitas estuvieron a punto de trasladarse a la provincia de Buenos Aires en la década de 1840. Por tanto, después de la extinción procederán como "exjesuitas” pero, como el padre Cantón lo señala, se comportarán como jesuitas ante la mirada de los demás. ${ }^{77}$

En particular se destaca la figura de Arrillaga - doctor en cánones por la Universidad de México (10 de julio de 1813) - , quien ya siendo clérigo y diácono de la arquidiócesis de México ingresó a la orden el 28 de julio de 1816 e hizo sus primeros votos el 31 de julio de 1818. Ya con 30 años de edad, después de 1821, a la vez que fungía como asesor jurídico en asuntos canónicos del cabildo catedralicio se convirtió en el principal publicista defensor de los derechos e intereses de la Iglesia. Como jesuita exclaustrado será su representante más conspicuo en los debates públicos nacionales. Esta posición le permitiría más tarde, en la década de 1830, ocupar un escaño en la Cámara de Diputados. Con la llegada, a mediados de diciembre de 1834, del nuevo gobierno opositor fueron electos como senador el padre José Rafael Olaguíbel (hasta su fallecimiento prematuro el 29 de septiembre

77 Carta del padre Cantón al padre general Juan Roothaan, 25 de agosto de 1830. AHPM, Correspondencia de la Provincia, 1816-1853-1-II, 16. 
de 1836) y como diputado el padre Arrillaga por el Distrito Federal, creado a fines de $1824 .^{78}$ En ese contexto, instalado el Congreso a principios de 1835, el oficial mayor del Ministerio de Justicia y Negocios Eclesiásticos, Joaquín de Iturbide ("católico liberal"), presentó una iniciativa que derogaba la ley de provisión de curatos del 17 de diciembre de 1833 y suponía la vigencia del Patronato. En este caso las nuevas cámaras eran hijas del Plan de Cuernavaca. ${ }^{79}$

\section{REINSCRIPCIÓN DE LOS JESUITAS \\ EN EL IMAGINARIO POLÍTICO}

1833 fue un año álgido. El 30 de marzo López de Santa Anna fue presidente por primera vez y Valentín Gómez Farías vicepresidente. El 1ํ de abril Texas solicitó su separación de Coahuila. El 3 de abril se fundó la Sociedad Mexicana de Geografía y Estadística. Mora fundó el Partido del Progreso. Ese año murió Fernando VII y subió al trono Isabel II bajo la regencia de su madre, María Cristina. El 21 de mayo ambas cámaras decretaron que el patronato residía en la nación, por lo cual se exigiría juramento a todos los prelados y superiores de ambos cleros. El cabildo catedralicio acudió a Arrillaga. Gómez Farías suprimió la Universidad donde enseñaba

78 Decorme, II, pp. 329-ss.

79 El Plan de Cuernavaca es el manifiesto sobre el que se respaldó el pronunciamiento político militar realizado el 25 de mayo de 1834 por Ignacio Echeverría y José Mariano Campos en contra de las reformas liberales en materia eclesiástica. Presuntamente el movimiento fue encabezado por Antonio López de Santa Anna, quien era el ejecutivo federal, siendo vicepresidente Valentín Gómez Farías, y que se enfocó a derogar muchas de las medidas establecidas por los liberales. Se dio lugar al establecimiento del llamado "gobierno centralista". 
Arrillaga, anuló la coacción civil para el pago de diezmos y el cumplimiento de votos religiosos, y el 17 de diciembre expidió la ley sobre la provisión de curatos por el Gobierno. El cabildo metropolitano reaccionó y el 30 de diciembre convocó a una reunión en la mitra incluyendo a Arrillaga. El 29 de abril de 1834 Santa Anna volvió a asumir la presidencia y Gómez Farías fue desterrado a Nueva York. Fue entonces, el 25 de mayo de 1834, cuando Santa Anna lanzó el Plan de Cuernavaca. Durante las elecciones de diciembre de ese año Arrillaga fue elegido diputado por el D. F. El Congreso, antes liberal jacobino, fue ocupado por el bando contrario. Más tarde se verá a Arrillaga participando en la elaboración de las Siete Leyes Constitucionales (1836) y las Bases Orgánicas (1843).

Este vuelco político generó el resurgimiento de la cuestión del Patronato Indiano y la posibilidad del restablecimiento de los jesuitas y las órdenes hospitalarias. Es decir, se crearon las condiciones para que de nuevo germinara un clima favorable al jesuitismo, pero igualmente a su contraparte. Como se lee en El Fénix de la Libertad de principios de 1834: "La religión jesuítica causa imponderables males al estado; auxilios para que esta peste se corrija”. O bien en otros números en los que se condena que los eclesiásticos tomen parte en los asuntos temporales. $\mathrm{O}$ cuando se publica el decreto expedido por el congreso general ordenando que se cedan "en los estados los edificios que fueron conventos, colegios y oratorios de los exjesuitas, y que se hallan situados dentro de sus respectivos territorios, no estando legalmente enajenados". ${ }^{80}$

${ }^{80}$ El Fénix de la Libertad (23 ene. 1834), p. 4. 
Precisamente en 1834, el ahora provincial jesuita, Francisco Mendizábal, le escribía al superior general P. Roothaan sobre el cambio de gobierno que hacía correr el rumor de la suspensión del decreto de las cortes españolas del año $20 .{ }^{81}$ Unos meses después le consultaba sobre cuál sería la mejor manera de llevar adelante el asunto en caso de hacerse efectiva la idea de restablecer las misiones en la Alta California u otros ofrecimientos para abrir algún colegio, como en el caso de un ciudadano de Toluca. ${ }^{82}$

En forma paralela, el historiador Carlos M. Bustamante, respaldado también por la llegada del nuevo gobierno, se dio a la tarea de editar obras de algunos jesuitas del exilio en suelo italiano. Así, por ejemplo, en septiembre de 1835 difundió el testimonio del exjesuita poblano Antonio López de Pliego sobre "el modo con que entraron y salieron los padres jesuitas de la Provincia de México, e idea del viaje de uno de éstos a Italia, en que describe las costumbres de aquel país". ${ }^{83}$ En su presentación Bustamante acentuaba el espíritu patriótico puesto a toda prueba del jesuita "desterrado inocente", algo que no deja de impresionar "en el corazón del que las oye, interesando a su favor a las almas sensibles". En ese sentido la lectura de su introducción es un canto al sentimiento nacional, y más cuando en esos días, escribía, los extranjeros no dejaban de burlarse de la patria. "Para reprimir, pues, en alguna manera este desmán, y que tengan mis paisanos un texto exacto con qué acallar tan injustas murmuraciones,

\footnotetext{
${ }^{81}$ Mendizábal al padre Roothaan, 22 de noviembre de 1834. AHPM-C, 1-II, 31.

${ }^{82}$ Mendizábal al padre Roothaan, 30 de abril de 1836, AHPM-C, 1-II, 37.

83 Bustamante, Diario Histórico de México, 1822-1848. Anexos, septiembre de 1835, n. 4.
} 
me ha parecido presentarles este viaje en lo conducente a tal objeto." Al mismo tiempo llama la atención sobre el talante humanista y profundamente civilizatorio ("cuando no solo se humanaron con los gentiles de Californias para hacerlos hombres, y después cristianos, sino que hicieron cosa que conmueven el corazón más frío [...]”) de aquellos jesuitas expulsados injustamente por Carlos III. Ahí aparecen algunos de los nombres clásicos del padre Salvatierra, Clavijero, Abad, Landívar y Cavo. ${ }^{84}$

Poco después, en 1836, Bustamante preparó la edición del manuscrito del exjesuita Andrés Cavo. ${ }^{85}$ Inflamado igualmente de espíritu nacionalista comenta que Cavo ofrece a sus "conciudadanos una historia completa" de lo ocurrido "en esta República durante el gobierno Español de trescientos años y diez y siete días". Por una feliz casualidad había caído en sus manos esa "historia autógrafa" escrita en Roma, de la cual tenía noticia por su hermano Lorenzo Cavo, con la que el sabio jesuita "recordaba a su querida Patria sin cesar". Bustamante la retomó hasta el momento de la expulsión y él mismo la había continuado hasta la entrada del Ejército Trigarante a la ciudad de México. Habiendo sido una empresa ardua decidió respetar el estilo y sólo corrigió alguna palabra

${ }^{84}$ Bustamante, Diario Histórico de México, 1822-1848. Anexos, septiembre de 1835, n. 4.

85 Bustamante, Obra escrita en Roma por el padre Andrés Cavo de la s. j., 1836. Andrés Cavo, Los tres siglos de México durante el Gobierno español, que podría considerarse la continuación de la historia de Clavijero y "primer compendio de historia patria", si bien se concentra en la historia de la ciudad de México. Decorme, I, p. 366. De Cavo se conoce recientemente la Vida de José Julián Parreño natural de la Habana con una excelente presentación, "Jesuitas nómadas entre América y Europa”, y edición de María Dolores González-Ripoll, pp. 13-84. 
menos castiza. Ofrecía la obra a los "buenos Mexicanos" que habían hecho posible la edición, a quienes miraba como "verdaderos patriotas, amigos de la gloria de la Nación, y protectores de su bella literatura". ${ }^{86}$

Bustamante no fue el único publicista en hacer elogio de los jesuitas en ese momento. Indirectamente su defensa está también presente en uno de los escritos rivales: en la interpretación de la historia reciente de México que publicó Mora en $1836 .{ }^{87}$ En particular, en el tomo II se dibuja a los jesuitas como precursores de la independencia. En este caso Mora se refiere al descontento popular originado en las medidas de Carlos III que condujeron al "extrañamiento" de los jesuitas:

Las dificultades pues de extrañar a los jesuitas eran muy grandes en España, pero incomparablemente mayores en un pueblo teocrático como el de México, que por la profunda ignorancia en que se le había tenido, lejos de hallarse en el caso de conocer las ventajas de esta medida, no podía menos de advertir el inmenso hueco que iba a resultar en la educación pública, en las misiones, en el culto, y en otras muchas cosas, algunas de importancia real y otras de ficticia, por el extrañamiento de una orden que para todo se había hecho y se reputaba necesario, y bien o mal lo desempeñaba todo. ${ }^{88}$

${ }^{86}$ Bustamante, Obra escrita en Roma, la rúbrica es del 18 de julio de 1836. ${ }^{87}$ Mora, México y sus revoluciones, ts. I y II.

${ }^{88}$ Mora, México y sus revoluciones, t. II, pp. 228-230. La reacción popular en contra del "extrañamiento" es descrita en las pp. 236-237. "Al cabo de tantos desórdenes consecuentes a una revolución que sobre ser la primera había estallado fuera de tiempo, los conspiradores, entre los cuales no había aparecido hasta entonces sino gente de poco valer, pensaron en decir algo, y establecieron por tema o mote de su empresa el siguiente: Nuevo rey y nueva ley, tuvieron proyectos de crear nobleza y otras mil extravagancias...”. Mora, México y sus revoluciones, t. II, p. 237. 
No obstante, Mora también incluyó en su argumentación la supuesta ambición de los jesuitas de pretender acaparar toda la educación. De tal modo que a la par del elogio se mantenía la leyenda negra antijesuítica, como la estrofa satírica aparecida en forma de salmo paródico republicano: "Fue llevado Buenrostro entre filas hasta Puebla. El alma nos ha de arder si cantan victoria los hijos de Loyola" ${ }^{89} \mathrm{O}$ aquella otra descalificación sarcástica: "A otro perro con ese hueso, porque yo no creo mucho en las lágrimas de los jesuitas. A lo menos uno que conozco está tan gordo, tan contento, y tan bien puesto en cuanto a la pecunia, que ni una lágrima ha de derramar, a no ser que tome una libra de rapé". ${ }^{90}$

\section{HACIA EL NUEVO “RESTABLECIMIENTO”}

El provincial Mendizábal, un día antes de fallecer, el 20 de mayo de 1841, envió una representación formal al Congreso solicitando el restablecimiento. ${ }^{91}$ En este comunicado se menciona lo injusta que fue la supresión de 1821, a la vez que muestra su extrañeza de no haberse corregido dicha injusticia con la independencia $;{ }^{92}$ más aún, conociendo que la orden había sido reconocida por otros sitios como Estados Unidos,

89 Publicado en Don Simplicio (1839) y reproducido en Bustamante, El nuevo Bernal Díaz del Castillo, t. II, pp. 9-10.

${ }^{9}$ El Quebranta Huesos (26 jun. 1841), p. 3.

${ }^{91}$ Representación que al Soberano Congreso dirige el Presbitero Francisco Mendizábal.

92 "Y que el sol de la libertad, este sol brillante y hermoso que alumbra los horizontes, las campiñas, hasta las más hondas cavernas del país de Moctezuma, haya dejado un solo rincón envuelto en aquellas tinieblas que por todas partes disipa. En efecto nuestros artistas han visto pasar veinte años de una santa y gloriosa revolución, sin dejar por eso de gemir 
España o Colombia y Buenos Aires. Asimismo planteaba a los congresistas que, dejando atrás el pasado, los jesuitas podían ahora perfectamente colaborar en la formación de ciudadanos conscientes de sus deberes y obligaciones, y proporcionar una educación integral en todos los niveles ${ }^{93} \mathrm{y}$, además, cubrir áreas misionales en las Californias, trabajar con los apaches y tarahumaras, y contener las correrías de los comanches y nayaritas y "todas las tribus innumerables que pueblan aquellas regiones [...]". Ese era el plan que proponía "para hacer la felicidad y la gloria de los pueblos del Anáhuac". ${ }^{94}$ Concluía solicitando un voto de confianza: "Créame, no somos tan malos como nos pintan nuestros enemigos". ${ }^{95}$

Al fallecer Mendizábal fue relevado en el cargo como viceprovincial por el padre Arrillaga, quien en ese momento fungía como senador de la República por México, Puebla y Oaxaca para el periodo 1838-1841. ${ }^{96}$ Un día después, el 22 de mayo, Bustamante se pronunció abiertamente a favor de la restauración jesuítica. ${ }^{97}$ Se presentaba como alguien que

en su antigua desgracia”, Representación que al Soberano Congreso dirige el Presbítero Francisco Mendizábal.

${ }_{93}$ Representación que al Soberano Congreso dirige el Presbitero Francisco Mendizábal, pp. 6-8.

${ }^{94}$ Representación que al Soberano Congreso dirige el Presbitero Francisco Mendizábal, pp. 9-10.

${ }^{95}$ Representación que al Soberano Congreso dirige el Presbitero Francisco Mendizábal, p. 16. Rúbrica: México, 19 de mayo de 1841. Decorme, I, pp. 363-364.

${ }_{96}$ Decorme, t. I, pp. 363-64. Ahora puede parecer extraña la presencia de eclesiásticos en las cámaras, pero se sabe que su participación fue relevante por lo menos hasta la década de 1850. Al respecto, Sordo Cedeño, "Los congresistas eclesiásticos en la nueva república", pp. 553-599.

97 Bustamente, en Defensa de la petición hecha al Soberano Congreso, 1841. Decorme, t. I, p. 365. 
de joven había recibido la influencia antijesuita y, pasados los años, con la experiencia y la lectura imparcial, había pasado de ser impugnador a panegirista. Había podido reconocer que una cosa eran los hechos y otra lo que se decía de los jesuitas. Por ese motivo había recolectado 176 firmas de católicos respetables encabezados por los obispos José María de Jesús Belaunzarán, Joaquín de Madrid y Antonio Campos para solicitar la reposición de los jesuitas. Cuando ya la tenía redactada y en prensa se había enterado de la propuesta de Mendizábal con idénticas proposiciones y, no obstante, decidió hacerla llegar al Congreso por medio de tres diputados.

Por su parte, el padre Arrillaga había restablecido la comunicación con su antiguo condiscípulo Ignacio Lerdo de Tejada, asistente del general en Roma. Le comenta que en México "las cosas políticas" siempre estaban "en peligro de turbarse", y con ello las cosas religiosas "sin ir a peor" no mejoraban. ${ }^{98}$ Seis meses después le informaba del fallecimiento de Mendizábal y de su nombramiento, así como de la solicitud presentada ante el Congreso, la cual ya no le había dado tiempo de corregir en algunos pasajes inconvenientes o un tanto ingenuos, pero no lo había hecho también porque como congresista su situación era bastante delicada, aunque para su sorpresa luego Bustamante se le había adelantado con la exposición "firmada por muchos ciudadanos". 99

La reacción a dichas representaciones no fue completamente favorable. Arrillaga menciona el apoyo del ministro del interior ("Ximénez"), excatedrático en el colegio de

${ }^{98}$ Carta de Arrillaga al P. Ignacio M. Lerdo, 8 de enero, 1841. AHPMC1816-1853, 1-II, 55.

${ }^{99}$ Carta de Arrillaga al P. Lerdo. 6 de junio de 1841. AHPM-C18161853, I.III,1. 
Puebla, quien no le había dado curso a la solicitud amedrentado seguramente por las críticas hirientes de algún periódico o por no estar completamente de acuerdo con lo expuesto por Mendizábal. Finalmente la propuesta fue asumida por cuatro diputados. Pero casi al momento de ser discutida a principios de junio se desató nuevamente la reacción en su contra por los liberales denunciando

[...] el despotismo de N. P. General la subordinación de los Jesuitas mexicanos a un extranjero, y riqueza futura de la Compañía, cuya proximidad infieren del mismo hecho de haberse propuesto por el Padre Mendizábal, que nos restablezcan, aunque sea sin darnos los antiguos bienes. ${ }^{100}$

En efecto, a partir de junio aparecieron en la prensa numerosas reacciones a favor y en contra de los jesuitas. El Cosmopolita reeditó el "Breve de la extinción de la Compañía de Jesús del papa Clemente XIV” de 1773. Juan Suárez Navarro, alumno del extinguido Instituto de Ciencias y Artes de Jalisco y quien se dice pensar como Jovellanos sólo en su patria "no en sus intereses partidistas", publicó Juicio crítico sobre el restablecimiento de la Compañía de Jesus o investigaciones filosófico políticas, sobre si conviene en las presentes circunstancias reponerla en la República Mexicana; Vicente García Torres, en el folletín "Idea de san Ignacio de Loyola o lo que son los jesuitas", retoma una publicación de Barcelona de 1839 en la que se dice que en la mente del fundador llegó a rondar la idea del suicidio; Ignacio Cumplido, por su parte, en "Contestación muy interesante al aviso muy impor-

100 Carta de Arrillaga a P. Lerdo. 6 de junio de 1841. AHPH-C18161853, I. II 1. 
tante de Puebla", respondía a un libelo poblano en contra del "venerable Palafox" y a la edición de Bustamante de la historia del padre Alegre. En "Cuatro palabritas sobre los Jesuitas”, El Quebranta Huesos difundía una sátira para desprestigiar a los jesuitas y dibujarlos como una amenaza para la libertad y tranquilidad de los pueblos.

Arrillaga sugiere que en la discusión y decisiones del Congreso influía la cuestión de las temporalidades de los jesuitas. No obstante que la solicitud incluía la renuncia a las antiguas temporalidades - con el problema, en su opinión, de que sin fundaciones no podía haber obras - Arrillaga anotaba el interés que tenía uno de los líderes del "partido liberal” y uno de sus órganos periodísticos más influyentes en "los bienes de San Gregorio”. En sus cálculos, del total de los 40 diputados, 16 claramente se opondrían, y de los 24 restantes no había seguridad completa de que estuvieran a favor ("quién sabe qué saldrá a la hora"). Así que por lo pronto todo quedaba en manos de Dios y por iniciativa suya había solicitado a "cada uno de los nuestros" que dijeran nueve misas "por el buen éxito". Por su parte se propuso promover la iniciativa en algunos diarios y hacer ver que los jesuitas no representaban ninguna amenaza en varios países liberales como "Estados Unidos del Norte de América”. En esto contaba con el apoyo del arzobispo. Finalmente sugería que en caso de ser restablecidos debería nombrarse a un provincial de nacionalidad mexicana, no a un extranjero. ${ }^{101}$

Por recomendación de Arrillaga, Bustamante escribió en el mes de noviembre al prepósito general de la orden. Aludía

${ }_{101}$ Carta de Arrillaga al P. Lerdo, 6 de junio, 1841. AHPM-C1816-1853, I.III, 1. 
al debate desatado en la opinión pública, y le comentaba que en todo habían guardado la prudencia y moderación, virtudes cardinales en la búsqueda de la justicia y la verdad. En agosto había estallado una "revolución de armas" que se prolongó hasta octubre, después de la cual al parecer había recibido con beneplácito la posibilidad de que él se encargara de promover la reposición de "la Compañía de Jesús en esta América”, sobre todo por la necesidad de educación que tenía la juventud mexicana y la "propagación del evangelio en las muchas regiones de bárbaros que hoy nos hacen una guerra a muerte" ${ }^{102}$ Finalmente López de Santa Ana expediría un decreto por el que podrían establecerse misiones jesuíticas en "los Departamentos de California, Nuevo México, Sonora, Sinaloa, Durango, Chihuahua, Coahuila y Texas" (Tacubaya, 21 de junio de 1843). ${ }^{103} \mathrm{Al}$ respecto Arrillaga mostrará su decepción al considerar que sólo se les estaba usando como un muro de contención frente a los indios bárbaros. ${ }^{104} \mathrm{Ya}$ en 1845 Arrillaga añadió también su preocupación por la precariedad de la situación política del país. Se refería en particular a una rebelión política en el "Sur" que rápidamente había degenerado "en guerra de castas", habiendo síntomas de una conflagración general en todo el país. ${ }^{105}$ Por esas razones consideraba que, aunque deseable, el momento no era propicio

102 Carta de Carlos M. Bustamante al P. General, 18 de noviembre, 1841. AHPM-C1816-1853, 1-III, 4.

103 AHPM, I-III/23.

104 Arrillaga le comenta a Lerdo que en el decreto se daba más énfasis a la "civilización e integridad del territorio" que a la "salvación de las almas", AHPM-C, junio 24, 1843, 1-III/24.

${ }^{105}$ De Arrillaga a Lerdo, 29 de octubre, 1844. AHPM-C Mex1-III/45. 
para la reposición; en caso de darse, añadía, "todos tendríamos que dejar por medios violentos nuestros destinos". ${ }^{106}$

El 26 de febrero de ese año haría mención de una inesperada "metamorfosis política" originada en la caída en desgracia del gobierno de Santa Anna, con el consenso general de los partidos políticos, encabezada por los principios de la democracia liberal que les iban a dar "mucha guerra”. Según Arrillaga, si bien "aquel General nos causaba otros males ya insufribles y que pedían pronto remedio", era alguien que "tenía comprimida la imprenta, cuyo Reglamento se está formando ahora, y en él se prohíben los ataques directos a la Religión, dejando descubierto el flanco de los indirectos". Poco después, "entre susurros y risas malignas", Bustamante solicitaba de nuevo que se discutiera en la Cámara de Diputados el restablecimiento. ${ }^{107}$

\section{DESENLACE TRANSITORIO}

Entre 1845 y 1853 Arrillaga, primo del general Mariano Paredes y Arrillaga, ocupó el cargo de provincial de los jesuitas por carta del General de junio de 1845, recomendado seguramente por el padre Lerdo desde Roma. No obstante no haría su profesión solemne de cuatro votos, requisito para ocupar dicho cargo, sino hasta el 15 de agosto de 1851, probablemente debido a las intermitencias del periodo. En dicho lapso Arrillaga viviría de las dietas de la diputación, de sus honorarios como catedrático universitario y bibliotecario, de sus capellanías y

106 De Arrillaga a Lerdo, 26 de nov., 1844. AHPM-C, Mex1-III/45.

107 De Arrillaga a Lerdo, 21 de agosto, 1845. AHPM-C-1845-1853, Mex 1-III/52. 
como escritor, a partir de 1853, de El Ilustrador Católico. ${ }^{108}$

1845-1853 es un periodo particularmente crítico, de sobresaltos constantes tanto en el orden político interno como por la invasión estadounidense. En la crónica de esos años puede leerse que en septiembre de 1846 había habido una "revolución" que concluyó "en dos días y medio, sin tirar un tiro", pero suficiente como para destruir al gobierno y elevar al poder - escribe Arrillaga - "a la chusma del año de 28", comenzando por "entronizar a los hombres más exaltados e irreligiosos" y conformando juntas "políticas" que no hacían más que "atacar al clero y a la religión" con todo descaro. El mismo día en que escribía ( 2 de septiembre) había elecciones para el Congreso, entre "lo más escogido de estos impíos demagogos". El clero se había visto obligado a hipotecar sus bienes por 1000000 de pesos para la guerra con Tejas. El ejército estadounidense seguía avanzando y a la hora en que estaba escribiendo seguramente ya se encontraban en Monterrey. Él, por su parte, había empezado a publicar otro periódico en defensa de la religión, El Ilustrador Católico Mexicano. Hasta la aparición del segundo número, tenían 200 suscriptores. Y le recomendaba al padre Lerdo en Roma a su primo "el general Paredes" que estaba por salir a Europa. ${ }^{109}$

${ }_{108}$ De Arrillaga a Lerdo, 21 de noviembre, 1845. AHPM-C-1845-1853, Mex 1-IV/1; Arrillaga a Lerdo, 24 de enero, 1846. AHPM-C-1845-1853, Mex $1-\mathrm{IV} / 3$.

109 Arrillaga a Lerdo, 2 de septiembre, 1846. 1-IV. En efecto, El Ilustrador Católico Mexicano se publicó entre el 16 de septiembre de 1846 y el 31 de marzo de 1847. AHPM-C-1845-1853, Mex 1-IV/3. Aparecía los miércoles y constaba de 24 páginas; la suscripción mensual 6 reales en la capital y 7 fuera. Mariano Dávila, quien se describía como un "novicio de los dispersos” y sobrino de Arrillaga fue un colaborador estrecho. Véase Publicaciones periódicas mexicanas del siglo XIX, pp. 219-222. 
Lerdo de Tejada también supo de la invasión yanqui por medio de José Agapito Muñoz, un habitante de Jalapa: "Las circunstancias presentes de este país son las más críticas en que jamás se ha visto. A la guerra exterior que sostiene con Estados Unidos se agrega la triste situación interior, quizá más temible que aquélla". Lo anterior en caso de "darse un decreto por el Congreso por la hipoteca o enagenación de bienes eclesiásticos hasta la cantidad de quince millones de pesos [...]". ${ }^{110}$ En otra carta, del 27 de octubre de 1847, le informaba que los americanos ya ocupaban "la capital de Mégico y en su palacio flamea el pabellón de las estrellas. No tengo esperanza alguna de que pueda resistírsele sin auxilio extranjero. En cuantos encuentros ha habido han sido vencidos los mejicanos. El Gobierno se trasladó a Querétaro”. No obstante, en

[...] medio de tantos disgustos y del fundado temor de un porvenir más triste se me presenta de cuando en cuando una esperanza consoladora, y es que, dominado este país por los americanos en virtud de los principios que sigue su gobierno, podremos tener otra vez en este país a la Compañía de Jesús, y me parece ya verla extendida por las ciudades principales y por aquellos mismos lugares que fueron en otro tiempo teatro de sus conquistas evangélicas, conservando a unos la fe y ganando a otros para Jesucristo. Sería solo un buen deseo; pero esta idea me consuela y mitiga mi dolor. ${ }^{11}$

Así, con esa esperanza, al concluir la guerra, en 1849 se presentaron nuevas solicitudes para restaurar a los jesuitas. En

${ }^{110}$ De Jalapa escribe José Agapito Muñoz a Lerdo el 29 de enero, 1846. AHPM-1-IV.

${ }^{111}$ Muñoz a Lerdo, 27 de octubre, 1847. AHPM-1-IV. 
Chihuahua se expidió un decreto en el que se manifestaba el deseo "de tener Misioneros" que pudieran "aplacar el furor de los Indios bárbaros" que desolaban "continuamente aquel Estado". Lo mismo en Durango y Querétaro había excelente disposición en sus congresos estatales para restablecer a los jesuitas, sin conseguir nada definitivo debido al peso que tenían los liberales o representantes de un "mayor grado de civilización como hoy se llama al odio a la Religión". ${ }^{112}$ Este fue el caso del reconocimiento por el Congreso de Querétaro, finalmente abortado por la presión llegada desde el centro de la federación. ${ }^{113}$

Por último, con la llegada otra vez al poder de Santa Anna, el "seductor de la patria"114 expidió el 19 de septiembre de 1853 un decreto para que se dieran todas las garantías legales a fin de que se restableciera a la Compañía de Jesús. Por esa razón fueron reconocidos nueve miembros de la institución, entre ellos el ya anciano padre Plaza y el padre Guadalupe Rivas, recibiendo en posesión el Colegio de San Gregorio.

Además de la celebración pública en la capital, ${ }^{115}$ también en Puebla fue "solemnizada" la restauración de los jesuitas con

112 De Arrillaga a Lerdo, 10 de septiembre de 1849. AHPM-1-IV/19.

113 De Arrillaga a Lerdo, 9 de noviembre de 1849. AHPM-1-IV. Véase la defensa legal de los jesuitas firmada por Tranquilino Vega, Los jesuitas... (BNE).

${ }^{114}$ Sin ser entusiasta de este género narrativo, prefiero las buenas historias, debo reconocer el acierto de Enrique Serna (El seductor de la patria) en la denominación asignada a este personaje que llena la primera mitad del siglo XIX mexicano hasta su destierro, que paradójicamente corre en paralelo al último intento jesuítico por obtener su "restablecimiento". Santa Anna fue quien derrocó a Iturbide, el otro potencial valedor de los jesuitas.

115 Solemnidades con que se celebró en esta capital el decreto...1854, 18 p. AGN, Justicia y Negocios Eclesiásticos, vol. 169, exp. s/n, fs. 108-119. 
repiques de campanas, Te Deum en la catedral, cohetes, serenatas públicas, pendones y tambores de los barrios, y un carro alegórico con la efigie del fundador de los jesuitas. En los discursos pronunciados existe la convicción de que era necesario olvidar el pasado de los jesuitas que sus enemigos se empeñaban en recordar para contradecirlos. El padre Corral fue enfático al respecto: "Pero cuando nuestra senda y esperanza están adelante, es inútil fijar la vista hacia atrás”. ${ }^{116}$ Sin embargo al mismo tiempo sus defensores apelaban a sus logros misionales y a su sistema educativo tradicional para formar a la juventud. En uno de los discursos, seguramente del padre Corral, se advierte la voluntad de situarse en los desafíos de la época, en particular frente al peso creciente de las ciencias aplicadas o tecnológicas, que en el nuevo programa serían integradas al de las humanidades o bellas artes tradicionales. ${ }^{117}$

El agradecimiento público a Santa Anna por el restablecimiento, en el que aparece como "el ilustre restaurador", fue rubricado por una larga lista de firmas de notables en las que se pueden distinguir nombres propios bastante conocidos, como: Antonio García Cubas, José Joaquín Pesado, Mariano Riva Palacio, Luis Robalo, Ignacio Cortina Chávez, Manuel Agreda, Bernardo Couto, Juan Rodríguez de San Miguel, Octaviano Muñoz Ledo, Luis Gonzaga Cuevas, Antonio de Vértiz, Felipe Romero, Antonio de Icaza, José Ramón Malo, Ramón de la Cueva, Feliciano Candas, Germán Landa, Refugio Sanromán Cortina, Francisco María Beteta, Francisco Abadiano, José María Andrade, Hilario Elguero, Basilio José Arrillaga, Manuel Tejeda, etc. De alguna manera Santa Anna

116 Narración de las muestras de júbilo, 1853, p. 17.

117 Narración de las muestras de júbilo, 1853, p. 18. 
ocupaba ahora, como restaurador de los jesuitas mexicanos, el lugar que después de la independencia no pudo o se negó a desempeñar Iturbide. ${ }^{118}$

Sin embargo, una nueva revolución (Ayutla) evaporó rápidamente estos sueños y esfuerzos por reinscribirse en el nuevo México republicano y nacionalista. En 1855, Santa Anna tuvo que salir al destierro y el presidente sustituto, Ignacio Comonfort (antiguo alumno de Arrillaga en Puebla), expidió un decreto el 7 de junio de ese año en que se derogaba el decreto del 19 de septiembre de 1853, por el que Santa Anna había restablecido a los jesuitas en toda la República. ${ }^{119}$ Frente a la nueva supresión hubo varias reacciones importantes pidiendo la revisión y disolución del decreto. Por ejemplo, el 31 de octubre apareció un opúsculo firmado por un numeroso grupo de padres de familia que exigían el derecho de enviar a sus hijos a las escuelas de su preferencia. En particular se protestaba por el cierre arbitrario del Colegio de San Gregorio, único que había sido puesto en operación por los jesuitas restaurados. ${ }^{120}$ Como provincial, Arrillaga reforzó la reclamación con la publicación de dos opúsculos, uno más formal y otro de divulgación: Exposición del Provincial de la Compañia de Jesús, sobre el derecho de propiedad que su religión tiene al edificio que actualmente ocupa y a los bienes del Antiguo Colegio de San Gregorio de que está en posesión a consecuencia de su restablecimiento en esta capital (México, Establecimiento

118 Abadiano, Voto de gracias, 1853 (BNE).

119 AGN, Colección de Documentos Oficiales para la Historia de México, vol. 2, exp. s/n, fs. 412-413. Sobre este nuevo "retorno" abortado véase Dávila, Continuación de la historia, t. I, pp. 290-328. Véase también Palencia, "Los jesuitas en la ciudad de México", p. 404.

${ }^{120}$ Los jesuitas juzgados, 1855. 
Tipográfico de Andrés Boix, 1855), rubricado el 30 de noviembre de 1855, y el segundo, Sencillas observaciones que se esponen a la justificación y buena fe, acerca del colegio de San Gregorio, que ocupan los padres de la Compañia de Jesús (México, Imprenta de J. M. Lara, 26 de sept. 1855). ${ }^{121}$ En ambos se hacía el elogio y defensa de la tradición educativa jesuítica fincada alrededor de la ratio studiorum, y la descripción detallada de las formas de educar y formar a la juventud. Ese mismo mes de noviembre se publicó en El Omnibus una "Representacion que se elevó al Exmo sr. Presidente de la republica general d. Juan Alvarez a favor de los padres jesuitas". ${ }^{122}$

Desde luego a tales reacciones y manifestaciones se sucedieron casi simultáneamente contrarreacciones suscritas por los partidarios de la democracia liberal que había destronado a Santa Anna, y que hacían ostentación de la libertad de comercio, seguridad de las garantías individuales, constitución republicana, representativa y popular. "En esto estaba su fuerza; en que era una regeneración, una emancipación para el pueblo. Por eso aterró al partido de la inquisición y de los jesui-

121 "Representación que se elevó al Exmo sr. Presidente de la republica general d. Juan Álvarez a favor de los padres jesuitas”, El Omnibus nov. 23, 1855, p. 2. "Parte Política. Colegio de San Gregorio". Representación en defensa de su restitución, con firmas innumerables al calce. Hace la historia del colegio y su dotación, hacienda de Acolman, y su trabajo con los pobres indígenas. Y citan: "Dicen los padres jesuitas, que por su restablecimiento no atacan derechos de nadie, que se reducen a habitar el viejísimo edificio que merece al Sr. Gamboa [...]” El Republicano (19 nov. 1855), pp. 1-2; Editorial, "Restablecimiento de El Colegio de San Gregorio. Educación y civilización de la raza indígena”. Reproducen la anterior Representación publicada en El Republicano. El Monitor Republicano (20 nov. 1855), pp. 1-2.

${ }^{122}$ El Omnibus (23 nov. 1855), p. 2. 
tas, y por esto fue la única, la sola esperanza de todos los mexicanos." ${ }^{123}$ De hecho, el argumento a favor de la expropiación del Colegio de San Gregorio se fundamentaba en que había que entregarlo a los indígenas, a la vez que se criticaba a sus "panegiristas" por hacer el elogio de un sistema que sólo beneficiaba “a los hijos de los ricos”, y que lo hacían con el interés de atraerlos para hacerse de sus fortunas. "Que se nos diga qué pobre ha encontrado asilo en San Gregorio, en ese colegio creado para la instrucción de los indígenas entregado hoy a una compañía reprobada por la iglesia". ${ }^{124}$ A su vez otras fuentes insistían en estudiar "la historia de los jesuitas" y buscar "la causa de la impotencia de sus constantes esfuerzos en Francia, en ese suelo predilecto de sus ambiciones". ${ }^{125}$

"Hay épocas en que las paradojas se encuentran a la orden del día”. Con esta frase el editorial de El Monitor Republicano del 26 de noviembre de 1855 englobaba su análisis sobre “La representación a favor de los Jesuitas”. Y recomendaba a las mujeres, madres de familia, a dedicarse a las cosas del hogar y a no inmiscuirse en política. Afirmaba que no era verdad que se combatiera a los jesuitas por combatir a los luteranos. Carlos III no era luterano, sino que los expulsó por querer monopolizar la educación y fomentar el odio y la confrontación, como se demostraba en el caso del obispo Palafox. ${ }^{126}$

\footnotetext{
123 El Republicano. Periódico del Pueblo (4 sep. 1855), p. 1.

124 “La Raza indígena. Sus necesidades”, El Monitor Republicano (8 nov. 1855), p. 1.

125 “Estudiemos”, El Monitor Republicano (12 nov. 1855), p. 1.

126 El Monitor Republicano (26 nov. 1855), p. 1.
} 


\section{PARA CONCLUIR}

La provisionalidad marcó el retorno de los jesuitas a México durante el siglo xix. Tras la segunda supresión, de $1820-$ 1821 , cada nuevo intento de obtener el restablecimiento era respondido con la negativa, el rechazo y la crítica. Esta dinámica se repitió durante todo el siglo. Todavía en 1873, Sebastián Lerdo de Tejada, sobrino del jesuita Ignacio María Lerdo de Tejada, expidió un decreto de expulsión de los jesuitas, en particular de los extranjeros.

De este modo, hasta las reformas de fines del siglo xx, los jesuitas no gozarían del reconocimiento oficial por parte de los gobiernos mexicanos. En esa imposibilidad se pusieron en juego, como se ha sugerido, el recuerdo y la memoria de luchas y conflictos pasados de los jesuitas anteriores a la expulsión de 1767. A su vez los jesuitas y simpatizantes como Bustamante pondrían también en juego el legado de sus antepasados, principalmente el de los ámbitos educativos y misionales, de la ciencia y la promoción del sentido patriótico mediante la historiografía y las humanidades.

El siglo antepasado, sin duda, está lleno de equívocos y paradojas. Si los jesuitas habían surgido y crecido para librar luchas religiosas, políticas y culturales frente a la avanzada de los reformistas luteranos, calvinistas y anglicanos del siglo Xvi, ahora esas "guerras” se confundían y yuxtaponían con otras luchas alrededor de lo que se conocerá como la edad de la razón, del progreso técnico y la libertad. Y no es que los jesuitas no hubieran sido promotores en el pasado de lo que en la premodernidad se entendía por libertad, educación y conversión de los paganos al cristianismo y la civilización. Incluso que no hubieran demostrado durante su retorno una 
voluntad patriótica en la construcción de una nación próspera. Y, sobre todo, de dar señales constantes de querer olvidar el pasado para abrir paso a un nuevo futuro a partir de las nuevas reglas de la democracia liberal. Estos valores, de alguna manera, están presentes en el documento-testamento del padre Mendizábal de 1841, o en el discurso del padre Corral al celebrarse en Puebla el "retorno" de 1853.

Como Lorenzo de Zavala, pienso que buena parte de estos equívocos se originaban en el cariz propio de la época, inscrito en una mutación cultural profunda. Hacia 1820, Zavala escribía: "Nuestra generación ha sido transportada instantáneamente en una especie de esfera moral distinta de aquella en que vivieron nuestros padres". Un momento, continúa, sólo equiparable en su dimensión a aquel otro en el que "los conquistadores obligaron con la fuerza a obedecer su imperio y a adoptar sus instituciones". De ahí que al suscribir este pensamiento afirmara que sólo se estaba en el comienzo de un proceso en ciernes. ${ }^{127}$

La naturaleza de esa transformación y su dinámica oscilatoria entre los fantasmas del pasado y su conjura en el presente no consiguieron tener una salida satisfactoria. Pese a las buenas intenciones de los participantes acabaron triunfando los prejuicios de un lado y del otro, al servicio seguramente de otra clase de intereses. ${ }^{128}$ En ese sentido, dentro de esa provisionalidad e inestabilidad constante, de ese tener que vivir los jesuitas a salto de mata y hasta cierto punto en la "clandestinidad", la memoria histórica, como un arma de

127 Zavala, Ensayo bistórico p. 291.

${ }_{128} \mathrm{Al}$ respecto, desde la perspectiva jesuítica, véase el artículo “Antijesuitismo”, Diccionario histórico de la Compañía de Jesús, pp. 178-189. 
doble filo, acabará teniendo un gran peso. La historia para los jesuitas podría jugar tanto a su favor como en su contra. De esto se dieron cuenta los mismos jesuitas y sus defensores, como cuando los padres de familia imploraban al gobierno de Juan Álvarez en 1855 que no se trataba ya de debatir de cosas sucedidas en el pasado, sino de pensar en el bien de la nación y de la educación e integración de las poblaciones bárbaras.

En esa encrucijada, bañada por la intensificación del nacionalismo, surgirá un discurso en el que aparecen los jesuitas como gestores o precursores de la independencia nacional y como portaestandartes de la "Ilustración católica", que daría lugar igualmente a la invención de la leyenda del criollismo ilustrado, misma que tampoco será rebatida desde el bando liberal, sino incluso profundizada. Lo que sí es altamente plausible es que los jesuitas, preocupados en obtener su restablecimiento, fueron impulsores de la independencia en los años críticos de 1820-1821, con el resultado paradójico de la confirmación de su nueva supresión. Ahí sí con toda razón se les puede ver como precursores de la independencia nacional, y dado el resultado no deseado, como el inicio de la construcción de su aura como católicos ilustrados.

Por eso hemos preferido hablar de ese momento como marcado por la paradoja: los jesuitas apostaron por la independencia y recibieron a cambio la confirmación de su supresión, cuyos efectos se observarán en el modo como se reinsertarán en la vida nacional. En un artículo temprano muy bien documentado de 1976 - tal vez uno de los primeros surgidos desde el ámbito académico inspirado en la historia social del periodo-, Brian Hamnett califica dicho retorno de "abortado" por estar sumido en una contradicción: los jesuitas, 
anteriormente impulsores del patriotismo criollo, libertarios y críticos del sistema, ahora al regresar habían sido parte de la reacción contrarrevolucionaria, por lo cual tuvieron que pagar el precio de su no reconocimiento. ${ }^{129}$ Habían traicionado sus valores mostrados en el pasado. Yo más bien pensaría que no se trata tanto de una contradicción, sino de un retorno a un mundo que tendía a desvanecerse, sin que ninguno de sus actores estuviera preparado para enfrentarlo con plena conciencia, al estar sellado por la paradoja.

\section{SIGLAS Y REFERENCIAS}

AGN Archivo General de la Nación, Justicia y Negocios Eclesiásticos, México.

AHPM Archivo Histórico de la Provincia Mexicana de la Compañía de Jesús, México.

AHPM, GD Archivo Histórico de la Provincia Mexicana de la Compañía de Jesús, fondo Gerardo Decorme, México.

AHAM Archivo Histórico del Arzobispado de México, México.

BMLT Biblioteca Miguel Lerdo de Tejada, México.

BNE Biblioteca Nacional de España.

BN, CL Biblioteca Nacional de México, Colección Lafragua, México.

BCM Biblioteca de El Colegio de México.

Abadiano, Luis (ed.)

Voto de gracias al Exmo. Sr. Presidente de la República, D. Antonio López de Santa Anna, por el restablecimiento de la Sagrada Compañia de Jesús, México, Imprenta de Luis Abadiano, 1853.

${ }^{129}$ Hamnett, "The abortive re-establishment of the jesuits in Mexico, 1815-1820”, pp. 265-288. 
Aguilera Murguía, Ramón

"La Arquidiócesis de México: entre la Nueva España y el México Independiente (II)”, Efemérides Mexicanas, 16: 46 (ene.abr. 1998).

Alamán, Lucas

Historia de Méjico, desde los primeros movimientos en el año 1808 hasta la época presente, parte segunda, México, Imprenta de J. M. Lara, 1852, t. v.

Arenal, Jaime del

"El Plan de Iguala y la salvación de la religión y de la Iglesia novohispanas dentro del orden constitucional”, en Ramos Medina (comp.), 1998.

Arrillaga, Basilio Manuel

Examen crítico de la Memoria del Ministerio de Justicia y Negocios Eclesiásticos, leida en las Cámaras de la unión del año de 1835. En lo referente al segundo de sus ramos, y respuesta a sus argumentos a favor de la actual existencia del Patronato. Por el Doctor Basilio Arrillaga, Sacerdote Mejicano. Méjico, Imprenta de Galván, a cargo de Mariano Arévalo, 1835.

Exposición del Provincial de la Compañia de Jesús, sobre el derecho de propiedad que su religión tiene al edificio que actualmente ocupa y a los bienes del Antiguo Colegio de San Gregorio de que está en posesión a consecuencia de su restablecimiento en esta capital, México, Establecimiento Tipográfico de Andrés Boix, 1855.

Sencillas observaciones que se esponen a la justificación y buena fe, acerca del colegio de San Gregorio, que ocupan los padres de la Compañía de Jesús, México, Imprenta de J. M. Lara, 1855.

"Antijesuitismo"

Diccionario histórico de la Compañia de Jesús Biográfico-Temático, Charles E. O’Neill, S. J. y Joaquín Ma. Domínguez, 
S. J. (directores), tomo I, Roma, Madrid, Institutum Historicum S. J., Universidad Pontificia Comillas, 2001.

Bandini, Antonio y Francisco José Ponce

Contestación dada por algunas corporaciones, Imprenta Liberal de Moreno, abril 1, 1822, $16 \mathrm{p}$.

Bernabeu Albert, Salvador

"El vacío habitado. Jesuitas reales y simulados en México durante los años de la supresión (1767-1816)", en Historia Mexicana, LVIII: 4 (232) (abr.-jun. 2009), pp. 1261-1303.

BREÑA, Roberto

El primer liberalismo español y los procesos de emancipación de América, 1808-1824. Una revisión historiográfica del liberalismo hispánico, México, El Colegio de México, 2006.

Bustamante, Carlos María (ed.)

Diario Histórico de México, 1822-1848 Efemérides históricopolítico-literarias de México, Anexos, septiembre de 1835, publicadas por Carlos María Bustamante y dedicadas al Supremo Gobierno General, n. 4.

Obra escrita en Roma por el padre Andrés Cavo de la Compañía de Jesús. Publícala con notas y suplemento (adiciones) el Lic. Carlos María de Bustamante, dedicada a sus suscriptores protectores, t. I, México, Imprenta Abadiano y Valdés, 1836. Se trata de Andrés Cavo, Los tres siglos de México durante el Gobierno español. Historia de la Compañia de Jesús en Nueva-España. Tomo III que estaba escribiendo el P. Francisco Javier Alegre al tiempo de su espulsión. Publicala para probar la utilidad que prestará a la América Mexicana la solicitada reposición de dicha Compañia, Carlos Maria de Bustamante, individuo del Supremo Poder Conservador, 2 vols., México, Imprenta de J. M. Lara, 1841-1842.

El nuevo Bernal Díaz del Castillo, o sea, historia de la invasión de los angloamericanos en México, 2 tomos facsimilares, México, Imprenta de Vicente García Torres, en el exconvento 
del Espíritu Santo, 1847, Instituto Cultural Helénico, Instituto Nacional de Estudios Históricos sobre la Revolución Mexicana, Fondo de Cultura Económica, 1994.

Casillas R., Rodolfo

"Del Patronato al nombramiento de obispos. El inicio de un nuevo entendimiento", en Religiones y Sociedad, 6 (mayoago. 1999).

Castañiza, Juan Francisco

Relación del restablecimiento de la Sagrada Compañia de Jesús en el Reyno de la Nueva España, y de la entrega a sus religiosos del Real Seminario de San Ildefonso de México, México, Imprenta de D. Mariano Ontiveros, 1816.

Catalogus

Catalogus sociorum provinciae mexicanae Societatis Iesu et numerum quibus quisque fungitur, México, Oficina de Alejandro Valdés, febrero de 1820.

Cavo, Andrés

Vida de José Julián Parreño, un jesuita habanero, edición y estudio introductorio por María Dolores González-Ripoll, Madrid, Consejo Superior de Investigaciones Científicas, 2007 (original publicado en Roma, Imprenta de Salomón, 1792).

Churruca, Agustín S. J.

"Historia de la Provincia Mexicana de la Compañía de Jesús", en Jesuitas de México (otoño-invierno 1992).

\section{Continuación}

Continuación de la bistoria de la Compañia de Jesús en Nueva España, del P. Francisco Javier Alegre, Puebla, Imprenta del Colegio Pío de Artes y Oficios, 1888-1889, ts. I y II.

Connaughton, Brian

"La Secretaría de Justicia y Negocios Eclesiásticos y la evolución de las sensibilidades nacionales: una óptica a partir de los 
papeles ministeriales, 1821-1854", en Ramos Medina (comp.), 1998, pp. 127-147.

Connaughton, Brian (coord.)

1750-1850: La independencia de México a la luz de cien años. Problemáticas y desenlaces de una larga transición, México, Universidad Autónoma Metropolitana, Ediciones del Lirio, 2010.

Religión, política e identidad en la Independencia de México, México, Universidad Autónoma Metropolitana, Benemérita Universidad Autónoma de Puebla, 2010.

Costeloe, Michael P.

Church and State in Independent Mexico: A Study of the Patronage Debate, 1821-1857, Londres, Royal Historical Society, 1978.

"Cuatro palabritas"

"Cuatro palabritas sobre los jesuitas. O sea diálogo entre Fígaro y D. Pascual acerca del restablecimiento de la Compañía de Jesús en la República Mexicana”, en El Quebranta Huesos, Impreso por Rafael Pastor, 15 de junio, 26 de junio, 15 de julio, 31 de julio de 1841.

Dávila y Arrillaga, José Mariano

Los jesuitas en México, o memorias para servir a la historia del restablecimiento, destrucción y otros sucesos relativos a la Compañia de Jesús, en la República Mexicana, desde 1816 hasta la fecha; Formadas sobre auténticos testimonios y diversos escritos de la época, por un testigo ocular de la mayor parte de ellos, México, Imprenta de Juan R. Navarro, 1850.

Continuación de la Historia de la Compañia de Jesús en Nueva España del Padre Francisco Javier Alegre, Puebla, Imprenta del Colegio Pío de Artes y Oficios, 1789-1790, ts. I y II.

Decorme, Gerardo S. J.

Historia de la Compañia de Jesús en la República Mexicana durante el siglo XIX, t. I Restauración y vida de secularización, 1816-1848, Guadalajara, Tipográfica “El Regional”, 1914. 
Historia de la Compañia de Jesús en la República Mexicana durante el siglo XIX, t. II, Restauración y vida de secularización. 1848-1880, Guadalajara, Tipografía, Litografía y Encuadernación J. M. Yguiniz, Sucr. D. Guerra n. 235, 1921.

"Decreto"

"Decreto. Supresión de la compañía de Jesús, y restitución al cabildo de la iglesia de S. Isidro de esta corte, de los derechos y funciones que obtuvo al tiempo de su creación. Agosto 17 de $1820 "$.

Defensa

Defensa de la petición hecha al Soberano Congreso, por varios individuos solicitando la restitución de la Compañía de Jesús en la República Mexicana, y satisfacción a los señores editores del Cosmopolita que la han impugnado, México, J. M. Lara, 1841.

"Defensa"

"Defensa de los padres jesuitas, por Los Poblanos", Puebla, Oficina de Pedro de la Rosa, 1820.

Documentos

Documentos y Obras importantes sobre los Jesuitas: Cartas del Venerable Palafox, cartas provinciales de Pascal, traducidas al castellano, México, Impreso por Ignacio Cumplido, 1841.

El gabinete mexicano

El gabinete mexicano durante el segundo periodo de la administración del Exmo. Señor Presidente D. Anastasio Bustamante, hasta la entrega del mando al Exmo. Señor Presidente interino D. Antonio López de Santa-Anna, y continuación del cuadro bistórico de la Revolución Mexicana, escrito por Don Carlos María Bustamante, quien la dedica al Exmo. Sr. General y gobernador del departamento de Nuevo México D. Manuel Armijo, t. III, México, Imprenta de José M. Lara, 1842. 
Egido, Teófanes (coord.)

Los jesuitas en España y en el mundo hispánico, Madrid, Fundación Carolina, Marcial Pons, 2004.

Fernández de Lara y Arellano, Juan José

Retrato de los jesuitas, por el cura de Tepeyanco, pide el establecimiento de los jesuitas, Puebla, Pedro de la Rosa, 16 de julio de 1822.

Fernández de Lizardi, José Joaquín

"Reflexiones interesantes sobre la carta que se dice dirigida por N. SS. P. el señor pío VII, al señor don Fernando VII, con fecha del 15 de septiembre de 1820, por el pensador mexicano", México, Oficina de J.M. Benavente y socios, 1821, 12 pp.

García Cubas, Antonio

Geografía e historia del Distrito Federal, México, Instituto Mora, 1993 (1894, $2^{a}$ edición, facsimilar).

García Diaz, Tarsicio (coord.)

Independencia nacional, vol. Iv, Consumación, México, Universidad Nacional Autónoma de México, 1987.

Independencia nacional, vol. II, Morelos-Consumación, México, Universidad Nacional Autónoma de México, 2005.

Gómez Ciriza, Roberto

México ante la diplomacia vaticana. El periodo triangular 1821-1836, México, Fondo de Cultura Económica, 1977.

González Araujo y San Román, Pedro

Impugnación de algunos impios, blasfemos, sacrílegos, y sediciosos artículos del Código Anarquía, cuyo título es: Decreto constitucional para la libertad de la América, sancionado en Apatzingán a 22 de octubre de 1814, etc., México, Imprenta de la calle de Santo Domingo y esquina de Tacuba, 1816. http://www.senado2010.gob.mx/index.php?page $=20$ 
GonZÁlez y GonZÁlez, Luis

"El periodo formativo", en Daniel Cosío Villegas (coord.), Historia minima de México, México, El Colegio de México, 1973.

GuedeA, Virginia

En busca de un gobierno alterno: los Guadalupes de México, México, Universidad Nacional Autónoma de México, 1992. "La independencia (1808-1821)", en Wobeser (coord.), 2010.

Gumbrecht, Hans-Ulrich

“QQuiénes fueron los philosophes?”, traducción de María Pilar Vallés Ezquerrá y Guillermo Zermeño Padilla, en Torres Septién (coord.), 2002, pp. 229-351.

Gutiérrez Casillas, José S. J.

Jesuitas en México durante el siglo XX (con 20 retratos), México, Porrúa, 1972.

“La nueva CJ desde 1814”, en O’Neill y Domínguez (drs.), t. III, 2001.

Hale, Charles A.

La transformación del liberalismo en México a fines del siglo $X I X$, traducción de Purificación Jiménez, México, Fondo de Cultura Económica, 2002.

Hamnett, Brian R.

"The abortive re-establishment of the jesuits in Mexico, 18151820", en Ibero-Amerikanisches Archiv, 4:4 (1978), pp. 265288.

Revolución y contrarrevolución en México y el Perú (Liberalismo, realeza y separatismo 1800-1824), traducción de Roberto Gómez Ciriza, México, Fondo de Cultura Económica, 1978.

"Idea de San Ignacio de Loyola"

“Idea de San Ignacio de Loyola o lo que son los jesuitas”, México, Vicente García Torres, 1841. 
"Impugnación”

"Impugnación de las calumnias e imposturas inventadas contra la Compañía de Jesús, que se publicaron en algunos diarios de Veracruz, y se han reimpreso en esta Ciudad, con el título de Memorias para la historia de los Jesuitas”, Puebla, Oficina del Gobierno Imperial, 1822, 36 pp.

KnOwLton, Robert J.

"La Iglesia mexicana y la reforma: respuesta y resultados", en Historia Mexicana, xvinI: 4 (72) (abr.-jun. 1969), pp. 616-534.

Los bienes del clero y la Reforma mexicana, 1856-1910, traducción de Juan José Utrilla, México, Fondo de Cultura Económica, 1985.

La corneta,

“Cornetaso a los cerviles", Diario Constitucional, Mejico, t. 1, núm. 55 (24 feb. 1821), p. 234 (BN/FL).

Legislación mexicana

Legislación mexicana o colección completa de las disposiciones legislativas expedidas desde la independencia de la República, ordenada por los licenciados Manuel Dublán y José María Lozano, www. 500 años de historia de México en documentos.

Los jesuitas juzgados

Los jesuitas juzgados por los padres de familia y la prensa liberal y religiosa, o sea contestación a los nuevos ataques de sus adversarios en México, México, Tipografía de A. Boix, 1855, 43 pp.

Meza Oliver, Rocío y Luis Olivera López

Catálogo de la Colección Lafragua de la Biblioteca Nacional de México, 1811-1821, México, Universidad Nacional Autónoma de México, 1996.

Mier, Servando Teresa de (bajo el seudónimo de José Guerra)

Historia de la revolución de Nueva España, antiguamente Anábuac, o verdadero origen y causas de ella con la relación 
de sus progresos hasta el presente año de 1813, Londres, Imprenta de Guillermo Glindon, 1813.

Discurso del Dr. Servando Teresa de Mier sobre la encíclica del Papa León XII, $5^{a}$ impresión revisada y corregida por el autor, México, Imprenta de la Federación en Palacio, 1825.

Monreal, Susana, Sabina Parone y Guillermo Zermeño (coords.)

Antijesuitismo y filogésiutismo: dos identidades ante la restauración, México, Universidad Iberoamericana, 2014.

Mora, José Joaquín de

"Introducción”, en William Davis Robinson, Memorias de la revolución de México y de la expedición del general D. Francisco Javier Mina a que se han agregado algunas observaciones sobre la comunicación proyectada entre los dos oceános, Pacifico y Atlántico, escritas en inglés por y traducidas..., Londres, R. Ackermann, 1824.

Mora, José María Luis

México y sus revoluciones, edición y prólogo de Agustín Yáñez, México, Porrúa, 1977 [París, 1836), ts. I y II.

Narración

Narración de las muestras de júbilo con que la piadosa y civilizada Puebla celebró en los días 5 y 6 de octubre de 1853, el decreto de 19 del mismo espedido por el gefe supremo de la nación general D. Antonio López de Santa-Anna, que restableció en toda su plenitud el instituto de la Compañia de Jesús, Puebla, Imprenta de José María Rivera, 1853, 24 pp.

Noriega, Cecilia

La Diputación Provincial de México. Actas de sesiones 18211823, México, Instituto de Investigaciones Dr. José María Luis Mora, El Colegio Mexiquense, El Colegio de Michoacán, 2007, t. II. 
Olmedo S. J., Daniel

Manual de historia de la Iglesia, México, Buena Prensa, 1950, t. III.

O’Neill, Charles E. S. J. y Joaquín Ma. Domínguez, S. J. (dirs.)

Diccionario Histórico de la Compañía de Jesús Biográfico-Temático, Roma, Madrid, Institutum Historicum S. J., Universidad Pontificia Comillas, 2001, t. III.

Palencia, José Ignacio

“Los jesuitas en la ciudad de México", en Pérez Alonso (ed.), 1972.

Palomera, Esteban J.

La obra educativa de los jesuitas en Puebla (1578-1945), México, Universidad Iberoamericana, Benemérita Universidad Autónoma de Puebla, 1999.

Pérez Alonso, M. I. (ed.)

La Compañía de Jesús en México. Cuatro siglos de labor cultural (1572-1972), México, Jus, 1972.

Publicaciones periódicas mexicanas

Publicaciones periódicas mexicanas del siglo XIX: 1822-1855, coordinación y asesoría Miguel Ángel Castro y Guadalupe Curiel, México, Universidad Nacional Autónoma de México, 2000.

Ramos Medina, Manuel (comp.)

Historia de la Iglesia en el siglo XIX, México, Condumex, El Colegio de Michoacán, El Colegio de México, Instituto José María Luis Mora, Universidad Autónoma MetropolitanaIztapalapa, 1998.

"Reglamento provisional político del Imperio Mexicano"

"Reglamento provisional político del Imperio Mexicano", Dado en Palacio Nacional Palacio Imperial de México. 2 de 
noviembre de 1822, hecha su promulgación el 18 de diciembre de 1822. http://www.ordenjuridico.gob.mx/Constitucion/1823.pdf

Representación de la Diputación

Representación de la Diputación Americana a las Cortes de España, en $1^{\circ}$ de Agosto de 1811, con notas del editor inglés, México, reimpreso en la oficina de Alejandro Valdés, 1820.

Representación que a favor

Representación que a favor de la Compañia de Jesús hacen en particular algunos sugetos ecclesiásticos y seculares de la ciudad de Santiago de Querétaro suplicando su restablecimiento al supremo congreso constitucional del IMPERIO MEXICANO, Querétaro, Oficina de Rafael Escandón, 1822.

Representación que al Soberano

Representación que al Soberano Congreso dirige el Presbitero Francisco Mendizábal, Puebla, reimpresa en la casa de Juan N. del Valle, 1841.

"Representación que se elevó"

"Representación que se elevó al Exmo sr. Presidente de la republica general d. Juan Álvarez a favor de los padres jesuitas, en El Omnibus, nov. 23, 1855, p. 2.

Restitución al cabildo

Restitución al cabildo de la iglesia de S. Isidro de esta corte, de los derechos y funciones que obtuvo al tiempo de su creación, agosto 17 de 1820, www. 500 años de México en documentos.

Revuelta González, Manuel

"Claves históricas para una periodización fundamental”, en EgIDo (coord.), 2004.

RIASA

"Incitativo sobre la restitución de las religiones suprimidas", México, Imprenta de Mariano Ontiveros, 1821. 
Riesgo, Juan Miguel

Justo Reclamo de la América a las cortes de la nación, México, Oficina de Alejandro Valdés, 28 de octubre de 1820.

Riesgo, Juan Miguel et al.

Representación de la Diputación Americana a las Cortes de España, en $1^{\circ}$ de Agosto de 1811, con notas del editor inglés, México, reimpreso en la Oficina de Alejandro Valdés, 1820.

Memoria sobre las proporciones naturales de las provincias internas occidentales: causas de que han provenido sus atrasos, providencias tomadas con el fin de lograr su remedio, y las que por ahora se consideran oportunas para mejorar su estado, e ir proporcionando su futura felicidad, México, Imprenta de José María Ramos Palomera, 1822.

Ruiz de Apodaca, Juan

Bando del virrey JRA, por el que se da a conocer la real orden de 16 de septiembre de 1820, la cual le fue remitida por Porcel, fechada en Madrid el 18 de sept. de ese año, en el que se da a conocer el decreto de las Cortes de 17 de agosto de 1820, en el que se decreta la supresión en toda la monarquía española de la Compañía de Jesus, etc., México, 23 de enero de 1821.

Serna, Enrique

El seductor de la patria, México, Joaquín Mortiz, 2000.

Serrano Ortega, José Antonio (ed.)

El sexenio absolutista, los últimos años insurgentes. Nueva España 1814-1820, Zamora, El Colegio de Michoacán, 2014.

Solemnidades

Solemnidades con que se celebró en esta capital el decreto que restablece la Compañia de Jesús en toda la República Mexicana y discursos pronunciados en ellas, Mérida, Imprenta de Rafael Pedrera, 1854. 
Sordo Cedeño, Reynaldo

"Los congresistas eclesiásticos en la nueva república", en CoNNAUGHTON (coord.), 2010.

SuÁrez Navarro, Juan

Juicio crítico sobe el restablecimiento de la Compañia de Jesus o investigaciones filosófico politicas, sobre si conviene en las presentes circunstancias reponerla en la República Mexicana, México, Imprenta de Vicente Garcia Torres, 1841.

"Suscripción"

"Suscrición. Documentos y obras importantes sobre los jesuitas: cartas del venerable Palafox, cartas provinciales de Pascal”, México, Impreso por Ignacio Cumplido, 1841.

Torres Puga, Gabriel

Opinión pública y censura en Nueva España. Indicios de un silencio imposible 1767-1794, México, El Colegio de México, 2010.

"Las dos supresiones de la Inquisición en México, 1813 y 1820”, en Connaughton (coord.), 2010, pp. 133-159.

"El último aliento de la Inquisición (1815-1820)", en SERrano Ortega (ed.), 2014, pp. 77-105.

Torres Septién, Valentina (coord.)

Producciones de sentido. El uso de las fuentes en la bistoria cultural, México, Universidad Iberoamericana, 2002.

VÁzquez, Josefina Zoraida

"De la independencia a la consolidación republicana", en Nueva historia mínima de México, México, El Colegio de México, 2004.

VEGA, Tranquilino

Los jesuitas y la Constitución, o sea colección de los fundamentos legales que obran a favor del restablecimiento de la Com- 
pañia de Jesús en la República Mexicana, México, Imprenta de Luis Abadiano, 1850.

VIDAL-Rosset, Joseph

Qu'est-ce qu'un paradoxe, París, Vrin, 2004.

Villoro, Luis

"La revolución de independencia", en Historia General de México (Versión 2000), México, El Colegio de México, 2000.

Wobeser, Gisela von (coord.)

Historia de México, México, Secretaría de Educación Pública, Fondo de Cultura Económica, 2010.

Zárate Toscano, Verónica

Los nobles ante la muerte en México. Ceremonias y memoria (1750-1850), México, El Colegio de México, 2000.

Zavala, Lorenzo de

Ensayo histórico de las revoluciones de México desde 1808 hasta 1830, México, Instituto de Cultura Helénico, Fondo de Cultura Económica, 1985.

Zermeño Padilla, Guillermo

"La filosofía jesuita novohispana en perspectiva", en Alfonso Alfaro (coord.), Colegios jesuitas, México, Artes de México, 58 (dic. 2001), pp. 78-87.

"Libros jesuitas incautados y proscritos", en Margarita de Orellana (coord.), Biblioteca Palafoxiana, México, Artes de México, 68 (ed. bilingüe), 2003, pp. 61-68.

"Recuerdo ritual, retorno, extinción e independencia: los jesuitas en Nueva España/México (1767-1822)”, en Peer Schmidт, Sebastian Dorsch y Hedwig Herold-Schmidt (eds.), Religiosidad y clero en América Latina - Religiosity and Clergy in Latin America (1767-1850). La época de las Revoluciones Atlanticas-The Age of the Atlantic Revolutions, Viena, Colonia, Weimar, Bohlau Verlag, 2011, pp. 131-159. Ver- 
sión en italiano: "Estinzione, retorno e memoria rituale: I Gesuiti messicani fra Italia e Nuova Spagna (1767-1821)”, pp. 69-106, en María Matilde Benzoni y Ana María González Luna C., (coords.), Milano e Il Messico: dimensioni e figure di un incontro a distanza dal Rinascimento alla Globalizzazione, Jaca Book, Milán, 2010, pp. 69-106.

“México/Nueva España”, en Javier Fernández Sebastián (dir.) Diccionario político y social del mundo iberoamericano. Iberconceptos II, Madrid, Universidad del País Vasco, Euskal Herriko Universitatea, Centro de Estudios Políticos y Constitucionales, 2014.

Hemerografía

Águila Mexicana

El Quebranta Huesos

El Cosmopolita

El Fénix de la Libertad 